\title{
O MITO EM “A HORA E VEZ DE AUGUSTO MATRAGA” DE JOÃO GUIMARÃES ROSA
}




\section{DEDICATÓRIA}

Aos meus avós sertanejos, Fortunato Bernardo e Maria Francisca. 


\section{RESUMO}

O objetivo deste trabalho é analisar como João Guimarães Rosa reinterpreta o mito clássico de Dionísio em "A hora e vez de Augusto Matraga"; última novela de Sagarana. A estrutura mítica que possui a novela confirma-se não só pela trajetória de queda e ascensão de Matraga que a identifica com o mito clássico grego (além de outras narrativas como a biografia de São Francisco de Assis), como também pelos elementos míticos intrínsecos na narrativa.

Nessa reinterpretação mítica também podemos reconhecer, na nova postura de Matraga, um comportamento histórico do Brasil dos anos 30 e 40. Assim, temos, na atualização do mito dionisíaco, a racionalização do mesmo quando podemos enxergar nele uma discussão histórica em torno do Coronelismo vigente da época. Matraga, ao regenerar-se, deixa exemplo de comportamento para cada indivíduo de seu povoado na sua trajetória de renascimento (viés mítico) e, nesse novo comportamento, traz um início de nova ordem para o Coronelismo local (viés histórico). 


\section{ABSTRACT}

The object of this paper is analyze how João Guimarães Rosa recomprehends the classic myth of Dionisio in "A hora e vez de Augusto Matraga"; the last tale of Sagarana. The mythical structure that the tale has confirms itself not even because of the career of falling and rise of Matraga which identifies with the classic greek myth (besides, it is possible to compare the story to other ones, as the biography of São Francisco de Assis), but also because of the mythical elements in the tale.

In this mythical recomprehension we can recognize, in the new life of Matraga, a historical behavior of Brazil in the 1930s/1940s. So, we have, in this up-to-date reading of Dionisio's myth, the rationalization of itself when we can see a historical discussion about the current Coronelismo. Matraga, when he rises, is an example of behavior for each person from his village in his career of rising (in a mythical line) and, in this new behavior, he brings in a beginning of a new order to the traditional Coronelismo (in a historical line). 


\section{SUMÁRIO}

AGRADECIMENTOS

.06

INTRODUÇÃO.

p.07

1. CONSIDERAÇÕES ACERCA DO MITO

1.1. Breve comentário conceitual ..............................................................p.10

1.2. Declínio do mito ...................................................................................p.14

1.3. Permanência do mito ............................................................................p.16

\section{MITO EM MATRAGA}

2.1. Trajetória mítica .......................................................................................p.19

2.2. Matraga e a hagiografia de São Francisco de Assis..............................p.38

2.3. Elementos míticos ...........................................................................................p.44

3. MATRAGA E O BRASIL DA ÉPOCA ........................................................p.60

3.1. Nhô Augusto: afirmação do Coronelismo local .......................................p.62

3.3. Augusto Matraga: reconhecimento de um "mundo misturado" ...............p.66

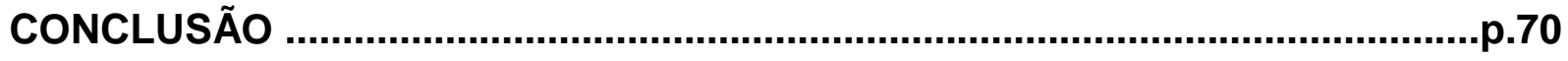

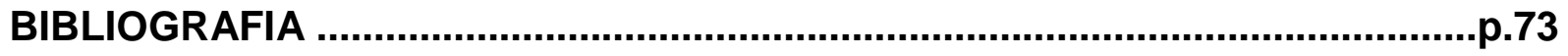




\section{AGRADECIMENTOS}

Ao professor Dr. Marcus Vinicius Mazzari, pela orientação precisa e pela generosidade.

Ao professor Dr. Luiz Roncari e à professora Dra. Ana Paula Pacheco, pelas sugestões e incentivos durante o exame de qualificação.

A todo o pessoal do Departamento de Teoria Literária e Literatura Comparada da USP, com especial deferência ao Luiz, responsável pela área de pós, pela simpatia, generosidade e eficiência.

Ao Newton da seção de alunos da graduação, pela simpatia e incentivo.

À amiga de sempre Andrea Rodsi, pelo incentivo constante.

Devo à CAPES a Bolsa de Estudos concedida.

Ao meu marido, pelo eterno companheirismo e apoio.

À minha querida mãe e aos meus irmãos que mesmo de longe sempre apoiaram este trabalho.

A Deus pela vida abençoada que me tem dado e por tudo que é possível agradecer. 


\section{INTRODUÇÃO}

Desde sua estréia no campo literário em 1946, João Guimarães Rosa tem sido considerado um dos maiores escritores da literatura brasileira. Sua rica obra compreendida em cinco livros publicados em vida e dois com publicação póstuma apresentam-nos, como já dizia Álvaro Lins ${ }^{1}$ num ensaio pioneiro sobre Sagarana, uma nova técnica de representação artística: a regional e a universal.

O sertão brasileiro (regional/histórico) toma espaço em suas narrativas como pano de fundo para os dramas da vida humana. Sua arte ficcional de representar a realidade sertaneja (nas descrições, no registro dos costumes, na fidelidade à linguagem e cultura populares, nas sutis divisões de classes) vale-se sempre de um outro plano menos claro que vai além do corriqueiro e convencional da vida do chão (universal/mítico), fazendo-nos muitas vezes ouvir os conselhos da narrativa, "seja num ensinamento moral, seja numa sugestão prática, seja num provérbio ou numa norma de vida"².

Logo, uma das principais dificuldades para o crítico literário está em classificar a obra desse escritor e "enquadrá-la" no hall artístico-literário das escolas do Brasil. Daí encontrarmos diversas linhas de análise na tradição da crítica rosiana.

Desta obra, destacamos, para este trabalho, a última novela de Sagarana, "A hora e vez de Augusto Matraga". Nossa análise da novela posiciona-se dentro da linha mítico-religiosa com um diferencial: também traz uma outra linha analítica, a histórico-social, que se oporia à primeira. De fato, algumas vezes, notamos que a posição tomada pelos críticos de Rosa fixa-se em um desses pólos, estabelecendo, assim, linhas estanques que não se complementam ou convergem.

A proposta aqui é deter-nos mais extensivamente na estrutura mítica que, ao nosso ver, possui a novela - mais especificamente, uma estrutura de atualização do

\footnotetext{
${ }^{1}$ LINS, Álvaro. “Uma grande estréia” In : COUTINHO, Eduardo F. (seleção de textos) Guimarães Rosa, Rio de Janeiro, Ed. Civilização Brasileira, 1991. (Coleção Fortuna Crítica)

2 BENJAMIN, Walter. "O narrador. Considerações sobre a obra de Nikolai Leskov" In : Obras escolhidas.

Magia e Técnica, Arte e Política. São Paulo, Brasiliense, 1998.
} 
mito dionisíaco de regeneração -, tentando mostrar também que essa estrutura pode denunciar um comportamento histórico-social do Brasil dos anos 30 e 40.

Para tanto, no primeiro capítulo, comentamos brevemente alguns conceitos sobre mito, baseados em mitólogos selecionados, tendo em vista a determinação do caminho a ser percorrido pelo trabalho; ou seja, nossa ênfase será dada no aspecto mítico-religioso da novela, porém mostrando que o mesmo pode ser complementado com o aspecto histórico-social, já que nos basearemos no conceito de que o mito, apesar de seu declínio com o surgimento da filosofia, permanece até nossos dias, trazendo em si próprio questionamentos fundamentais para o homem moderno inserido numa sociedade transformada que exige do mito também respostas práticas no âmbito de seu convívio social.

Desde já é importante deixarmos claro que não enxergamos mito e história em lados opostos e divergentes. Pelo contrário, pensamos que a história pode ser discutida no mito quando este, após seus momentos de ápice e declínio, teve de se transformar para atender às perspectivas do homem moderno. A questão está na atualização e na racionalização do mito; sua reelaboração através dos séculos necessariamente carrega reflexões sobre o homem, seus conflitos internos e sua intervenção no mundo, já que essas foram as exigências trazidas pelo aperfeiçoamento das relações humanas.

Dessa forma, o segundo capítulo se fixará na atualização do mito de regeneração; de que maneira Rosa reelabora o mito dionisíaco no sertanejo Augusto Matraga, rastreando desde aspectos mais latentes, como a trajetória de queda e ascensão do personagem, até os elementos míticos mais intrínsecos que percorrem a narrativa, como a mudança de nome, a marca de ferro e a identificação com a natureza. Esse segundo momento, portanto, vem a ser o cerne mesmo do trabalho já que a estrutura mítica da narrativa é o nosso foco principal.

Todos esses elementos ajudam-nos a compreender melhor como Rosa reinterpreta o mito clássico de Dionísio num personagem cuja realidade é a do sertão brasileiro, com toda sua aspereza e, ao mesmo tempo, sua força de renovação, utilizando-se, então, não só do simbolismo da queda e ascensão, como também 
aspectos sutis (nome, marca e natureza), mas de papel relevante no conjunto da narrativa.

Seguindo a idéia de permanência do mito e sua racionalização, o terceiro capítulo tenta trazer uma denúncia social contida na novela: na trajetória mítica do personagem há a problemática do Coronelismo vigente no sertão brasileiro. $\mathrm{O}$ primeiro Augusto como afirmação desse sistema (Coronel Augusto Esteves) e o segundo (Augusto Matraga) como reconhecimento do convívio do poder informal (Coronelismo) com o formal (senso de justiça adquirido em sua regeneração).

Essa mudança de comportamento, fruto de seu renascimento, reflete a mudança social pela qual passava o país desde a década de 30; a mudança, então, serve não só para o indivíduo Matraga, como também para o povoado, já que traz uma atitude diferente dos moldes do costume local. Portanto, não podemos deixar de apontar essa reflexão histórica na trajetória mítica de Matraga.

Com a leitura dos três capítulos, o trabalho propõe, assim, uma análise que, apesar de ter como centro a linha mítico-religiosa, também permite uma complementação ou diálogo com outra linha histórico-social, tentando uma análise que, distanciando-se um pouco de uma postura extrema de opostos, possa acrescentar algo novo na rica tradição crítica sobre a obra de João Guimarães Rosa. 


\section{CONSIDERAÇÕES ACERCA DO MITO}

\subsection{Breve comentário conceitual}

Apesar da questão do mito ser de fundamental importância para o trabalho presente, não é nosso objetivo definir o que é mito, tendo em vista a complexidade de seu conceito. Porém, passa a ser relevante uma breve discussão em torno de algumas visões de mitólogos aqui escolhidos pela importância dentro da crítica e pela seriedade com que tratam o assunto.

Partindo de uma visão mais moderna, ao designarmos uma narrativa como sendo mítica, geralmente, seguindo o senso comum, estamos nos referindo a uma história não verdadeira, carregada de crenças e difundida pela tradição oral - o que faz do mito um traço marcante no folclore de um povo. Esse conceito do mito nos tempos modernos dá-se justamente pela transição ocorrida entre uma época oral e outra escrita.

Sabemos que nesse mundo oral encontrava-se o mito que ainda possuía, segundo Vernant ${ }^{3}$, "a magia da palavra" e seu poder ilusório. Na ordem da fala, as narrativas míticas eram transmitidas oralmente num exercício de audição que difere do exercício da leitura. Aquele exercício era carregado de subjetividade e crenças e, por isso, ligado ao sagrado/religioso, ao passo que este último baseia-se no fator racional do pensamento humano.

$\mathrm{Na}$ linha do conceito de história sagrada, Eliade ${ }^{4}$ diz que o mito é história viva/verdadeira que revela as origens do mundo e do próprio ser humano; é a narrativa da criação, de um tempo primeiro, no qual tudo e todas as coisas passaram a existir, "seja uma realidade total, o Cosmo, ou apenas um fragmento: uma ilha, uma espécie vegetal, um comportamento humano, uma instituição." ${ }^{5} \mathrm{O}$ homem é colocado aqui como "produto dos eventos passados", deixando de lado o conceito de que mito é narrativa falsa ou subjetiva demais para ser levada em consideração.

\footnotetext{
${ }^{3}$ VERNANT, Jean-Pierre. "Razones del mito” In: Mito y sociedad en la Grecia antigua, Madrid, Siglo Veintiuno Editores AS, 1987.

${ }^{4}$ ELIADE, Mircea. “A estrutura do mito vivo” In: Mito e Realidade, São Paulo, Ed. Perspectiva, 2000.

${ }^{5}$ ELIADE, Mircea. Op. cit. p. 11.
} 
Essa história verdadeira estava intrinsecamente ligada ao homem desde seus primórdios. Da Era Paleolítica (do homem caçador) à Era Neolítica (do homem agricultor), o homem soube distinguir o papel do logos e do mito em sua vida: aquele para as técnicas da caça e da agricultura e este para a reconciliação com os animais e com a terra nos fatos trágicos da vida.

Em livro recente, Karen Armstrong ${ }^{6}$ diz que "um mito, portanto, é verdadeiro por ser eficaz, e não por fornecer dados factuais", ou seja, "se nos força a mudar corações e mentes, nos dá novas esperanças e nos impele a viver de modo mais completo, é um mito válido", é um mito vivo - será essa veracidade que, no correr dos tempos, como veremos, declinará.

O poder de transformação do mito ainda é notado nos ritos de iniciação, que remontam à Era Paleolítica, em sociedades tradicionais atuais. Os jovens tribais devem passar por privações, que incluem dores físicas e marcas no corpo (tatuagens ou circuncisões), que os transformarão em homens adultos - "esse é um processo de morte e renascimento"7 que transformará o jovem para sempre.

O mito, portanto, era (ou é) parte do dia-a-dia das pessoas, mais explicitamente nos primórdios históricos ou ainda em comunidades isoladas e tradicionais de nossa Era Moderna, posicionando-se, em todo caso, como algo necessário ao homem.

Outra visão que também traz a idéia de necessidade do mito é elaborada por Jolles $^{8}$, em seu estudo particular das Formas Simples, no qual coloca o Mito como produto desse desejo do homem de questionar o mundo, obtendo desse questionamento uma resposta, ou seja, "quando o universo se cria assim para o homem, por pergunta e resposta", temos o Mito (a Forma Simples literária) que se apresenta em suas atualizações isoladas nos mitos ou narrativas.

\footnotetext{
${ }^{6}$ ARMSTRONG, Karen. Breve história do mito. São Paulo, Companhia das Letras, 2005.

${ }^{7}$ ARMSTRONG, Karen. Op. cit. p.34.

${ }^{8}$ JOLLES, André. “O Mito” In : Formas Simples, São Paulo, Editora Cultrix, 1930.
} 
"Nunca existiu uma versão única e ortodoxa de um mito. À medida que as circunstâncias mudam, precisamos contar as histórias de modo diferente, para expor sua verdade intemporal." 9“

Esse reelaborar é fruto da imaginação humana que questiona e cria; "Mito é criação", diz Jolles; é a resposta para os questionamentos humanos no que se refere ao surgimento do mundo e seus seres.

Esses questionamentos são naturais ao ser humano independente da época histórica que recortemos, pois o homem sempre aspirou estar acima da condição humana. Para isso, fazemos uso de nossa capacidade mental de criarmos histórias que nos expliquem e nos situem no mundo.

“(...)desde a origem mais remota inventamos histórias que permitem situar nossas vidas num cenário mais amplo e nos dão a sensação de que a vida, apesar de todas as provas caóticas e arrasadoras em contrário, possui valor e significado". ${ }^{10}$

Então, temos o mito aqui ligado ao pensamento humano num ato de pergunta e resposta; ligação um tanto natural e, assim, não tão distante de nossa estrutura de pensamento. Vernant, ao se referir aos estudos mitológicos, diz que a dificuldade ou complexidade em tal atividade dá-se exatamente pelo fato de o mito ser natural ao pensamento ocidental, como o aprendizado da língua materna. Ou seja, o mito está tão enraizado em nossas estruturas de pensamento que se torna difícil o distanciamento necessário para estudá-lo - "cada niño aprende sin aprecibirse de ello, escuchando y repitiendo la tradición como aprende su lengua materna, son tanto menos perceptibles cuanto más naturales, más immediatas parecen." ${ }^{11}$

\footnotetext{
${ }^{9}$ ARMSTRONG, Karen. Op. cit. p.15

${ }^{10}$ ARMSTRONG, Karen. Op. cit. p.08

${ }^{11}$ VERNANT, Jean-Pierre. Op. cit. p. 188.
} 
Portanto, mesmo o senso comum tendo eleito como conceito mais difundido o de que o mito é uma narrativa falsa, ligada a uma era remota onde o pensamento racional propriamente dito não havia ainda se desenvolvido, a estrutura mental mítica ainda persiste como característica mais humana do que perece ser, independente de épocas, ou seja, estamos falando aqui de estruturas mentais e não mais de crenças - o homem deixou de crer piamente nas narrativas míticas, mas mantém suas estruturas mesmo no ato do raciocínio lógico. 


\subsection{Declínio do Mito}

Precisamos nos remeter à Grécia Antiga para entendermos de uma melhor maneira como se deu esse declínio do mito, pois as transformações ocorridas lá a partir do século VII a.C. ocasionaram a transição do pensamento mítico, até então vigente e que baseava toda a vida humana, para o pensamento científico-filosófico.

Na Grécia Micênica, a sociedade baseava-se na figura mítica do rei divino, superior a todas as coisas, detentor de um saber sagrado e oculto - "senhor do tempo". As terras eram coletivas e patriarcais (chamados genos), organizadas em aldeias com sua vida própria.

Com a chegada dos dórios ao Peloponeso, cai toda a estrutura do império micênico, desaparecendo, então, a figura de base: o rei divino, o que causa um desequilíbrio social, ou seja, torna-se necessária a reconstituição dessa sociedade: "a busca de um equilíbrio, de um acordo, fará nascer, num período de desordem, uma reflexão moral e especulações políticas que vão definir uma primeira forma de "sabedoria" humana"12. Temos, portanto, um primeiro passo para a formação futura de um pensamento racional/científico.

A estrutura patriarcal e agrária começa a perder forças, abrindo espaço para o que chamaremos de cidade-Estado ou a polis, o que exige reflexões em torno dessa nova formação social que difere bastante do antigo genos. Logo, as principais questões surgidas são colocadas em praça pública para discussão e conhecimento de todos, ou seja, inicia-se o processo de tornar público o que antes era sagrado e de domínio apenas do rei divino.

Os principais centros filosóficos, como podemos chamar, surgidos na Grécia antiga foram Mileto e Éfeso que se formaram com a fuga de aqueus e jônios da invasão dória para as ilhas e as costas da Ásia Menor.

Devido às suas posições geográficas um tanto estratégicas, esses centros desenvolveram muito bem o comércio, trazendo junto com esse desenvolvimento as expansões técnicas conseqüentes e a moeda nas transições comerciais. O homem 
passa a ter, de certa forma, um domínio técnico e matemático de seu cotidiano, de sua vida; as explicações para a resolução de problemas passam a ser experimentais e, logo, racionais.

Essas mudanças não ficam apenas no dia-a-dia desses povos, mas serão a base das mais simples às mais complexas questões existenciais humanas, como a política. As leis passam a ser escritas, já que a mentalidade humana necessitava de resoluções mais concretas, mais exatas e que estivessem ao alcance de sua inteligência ou exercício racional - as pessoas "não mais podiam ver os deuses da mesma maneira que seus ancestrais os viam"13.

Com isso, dá-se, como podemos perceber, um maior distanciamento daquele pensamento mítico e oral que mediava toda a antiga organização social e mental dos homens. Na transição da oralidade para o advento da escrita, temos uma mudança de pensamento crucial para o declínio do mito que já não comporta as explicações suficientes e convincentes sobre os problemas humanos e, portanto, sociais.

Essa nova mentalidade, segundo muitos historiadores, não teria origem exclusiva grega, devido aos contatos pré-existentes com o Oriente (na Grécia Micênica) que teria influenciado e transmitido ao povo grego um princípio de racionalidade; ou seja, com a Grécia teria nascido sim um pensamento científicofilosófico, "uma razão grega", fruto das circunstâncias e do processo histórico da mesma e "filha da cidade".

\footnotetext{
${ }^{12}$ VERNANT, Jean-Pierre. As origens do pensamento grego, São Paulo, Difel/Difusão Editorial S.A., 1977. $2^{\mathrm{a}}$ edição. Tradução de Ísis Borges B. da Fonseca.

${ }^{13}$ ARMSTRONG, Karen. Op. cit. p. 57.
} 


\subsection{Permanência do pensamento mítico}

"Na filosofia, o mito é racionalizado". Essa frase do mitólogo Cornford, citado por Vernant ${ }^{14}$, talvez possa explicar-nos o porquê dessa permanência do mito nos dias atuais - não que ainda haja crença nas narrativas míticas em nossos centros urbanos, como havia na Grécia Antiga, mas que ainda podemos notar uma estrutura mítica no pensamento ocidental herdada da antiga era da tradição oral.

Segundo Cornford, a razão não surgiu com os filósofos de Mileto ou Éfeso. Esses primeiros pensadores teriam discursado com a "mesma visão mítica original", ou seja, teriam se utilizado da mesma lógica mítica: um plano real (separação da terra das águas, por exemplo) e um plano imaginário (geração dos deuses no tempo primordial). Nessa mesma lógica estariam os primeiros discursos filosóficos quando discute, por exemplo, a questão da alma e do corpo ou do divino e do físico.

"As noções fundamentais em que se apóia esta construção dos jônios: segregação a partir da unidade primordial, luta e união incessante dos opostos, mudança cíclica eterna, revelam o fundo do pensamento mítico onde enraíza a sua cosmologia. Os filósofos não precisaram inventar um sistema de explicação do mundo: acharam-no já pronto."15

Ou seja, o que de novo os filósofos jônios trazem é a colocação do problema, o que antes o mito não o fazia; passam a discutir a ordem natural do mundo a partir das primeiras idéias míticas. Portanto, os primeiros pensadores vão, na verdade, discutir o que o mito já colocava, vão racionalizar o mito.

\footnotetext{
${ }^{14}$ VERNANT, Jean-Pierre. "Do mito à razão" In : Mito e pensamento entre os gregos, São Paulo, Difusão Européia do livro, Edusp, 1973. p. 298.

${ }^{15}$ VERNANT, Jean-Pierre. Op. cit. p.298.
} 
Dessa forma, não perdemos completamente a "estrutura básica" do mito, muito pelo contrário; conforme Eliade ${ }^{16}$ relata, o pensamento mítico não sumiu por inteiro, havendo resistências nas mais diversas formas de manifestação: nas áreas rurais dos interiores das sociedades podemos notar com bastante freqüência a importância dada às narrativas míticas que ainda são passadas de geração em geração.

Não só em manifestações tipicamente míticas, mas também em comportamentos. Eliade nos traz como exemplo o Cristianismo que se fundamenta na imitação e seguimento dos passos de seu modelo maior Jesus Cristo para, assim, obter a salvação da alma, além de ter nos santos do Catolicismo o reflexo da influência dos deuses míticos - o mito da cristandade é válido pela sua eficácia de transformação.

Será de bastante relevância o tema da religiosidade neste trabalho; portanto, estudaremos o papel do fator religioso nas sociedades - e, obviamente, no corpus literário escolhido -, mas o nosso ponto de vista parte de uma visão do religioso como sendo um comportamento estruturalmente mítico. Vemos que a religião (ou o comportamento religioso) é uma das manifestações míticas, isto é, não vemos religião e mito como pontos estanques e divergentes, pois entendemos que 0 comportamento humano baseia-se em estruturas míticas, cabendo, dentre elas, a religiosidade.

Também temos como uma sobrevivência do mito, mesmo que seja através de um registro bastante diferente do mito original, o discurso literário. O que impressiona à primeira vista é o fato de que os mitos gregos foram, a partir da Renascença e sobretudo a partir do século XVII, os textos mais reinterpretados pelos escritores. Segundo Martinon ${ }^{17}$, "eles (os mitos) fazem parte da definição da literatura".

Segundo Karen Armstrong, "têm sido os escritores e artistas, e não os líderes religiosos, a penetrar no vácuo para tentar a reaproximação com a sabedoria mitológica do passado". Ela cita Picasso, Eliot, Joyce, Borges, Günter Grass, Ítalo

\footnotetext{
${ }^{16}$ MIRCEA, Eliade. “Sobrevivências e camuflagem dos mitos” In : Mito e Realidade, São Paulo, Perspectiva, 2000.

${ }^{17}$ MARTINON, Jean-Pierre. "O mito da literatura” In : Atualidade do mito (Tradução de uma coletânea de artigos publicados na revista Esprit, n 402, abril de 1971). São Paulo, Livraria Duas Cidades, 1977.
} 
Calvino, entre outros, como romancistas e artistas que "desafiaram a hegemonia do logos ao combinar elementos realistas com outros inexplicáveis, e a racionalidade atual com a lógica mítica dos sonhos e contos de fadas". ${ }^{18}$

Assim, desde a pura crença nos mitos (ainda vigente em comunidades mais distantes dos grandes centros) até o registro literário (de domínio central nas cidades), o pensamento mítico não desapareceu para dar lugar à filosofia. Ele permanece em nossas maiores e menores esferas sociais sob suas formas atualizadas e racionalizadas, seguindo as linhas de Jolles e Cornford respectivamente.

João Guimarães Rosa não deixou de ser um desses novos elaboradores do mito. Das várias vertentes existentes na fortuna crítica da obra do autor, uma das mais exploradas é a visão mítico-religiosa de sua obra, da qual destacamos, para este trabalho, a novela "A hora e vez de Augusto Matraga" de Sagarana.

Nela podemos afirmar que temos uma atualização do mito de regeneração ou renascimento, ao passo que também temos a sua racionalização quando traz, por entre essa estrutura mítica, fatos históricos/empíricos do Brasil da época. Nosso objetivo, portanto, é rastrear toda essa estrutura da novela, considerando seus principais elementos de atualização e racionalização do mito.

\footnotetext{
${ }^{18}$ ARMSTRONG, Karen. Op. cit. p.118.
} 


\section{MITO EM MATRAGA}

\subsection{Trajetória mítica}

Iniciando pelo que há de mais latente na novela, observamos que a trajetória de vida de Matraga assemelha-se com o que chamamos de mito de regeneração ou renascimento - dentro de Sagarana, não encontramos nenhuma outra novela na qual houvesse um processo de transformação de fato do personagem central, aliás, dentro da obra roseana, talvez, possamos afirmar que esta é a única narrativa que trabalha esse tema ${ }^{19}$.

Em "A hora e vez de Augusto Matraga", o personagem central vivencia várias fases durante sua trajetória de reconstrução - fases vividas na idade já adulta, pois a novela nos traz Matraga já casado, com filha e com um status herdado da família, ou seja, Matraga possui apenas o que foi deixado pelo pai como seu legado.

Nesse percurso, notamos três grandes passos dados pelo personagem que podem ser imaginados numa escala que começa numa postura radical de coronel e termina em outra postura transformada miticamente.

\section{Primeira Fase}

Sua primeira fase mostrada na narrativa, traz o homem sem rédeas, detentor de um resquício do coronelismo paterno, ou, usando, um vocábulo muito comum na novela "Corpo Fechado", ele á o valentão do Córrego do Murici. Em cenário sagrado - leilão inicial -, Matraga nos é apresentado na narrativa pelos vários adjetivos atribuídos a sua pessoa:

E, aí, de repente, houve um deslocamento de gentes, e nhô Augusto, alteado, peito largo, vestido de luto, pisando pé dos outros e com os braços em tenso,

\footnotetext{
${ }^{19}$ Daí a posição de destaque que se encontra a novela perante a crítica literária.
} 
angulando os cotovelos, varou a frente da massa, se encarou com a Sariema, e pôs-Ihe o dedo no queixo. Depois, com voz de meio-dia, berrou para o leiloeiro Tião:

_ Cinqüenta mil-réis!..." ${ }^{20}(p .325)$

Notamos a importância dada ao físico de Matraga e sua voz "de meio-dia" que berra, quase como algum animal de porte (poderíamos pensar no boi, animal tão contemplado por Rosa).

E mesmo em cenário sagrado, Matraga arremata a Sariema sob os protestos do leiloeiro Tião, sublinhando sua figura de "homem sem detença" ou, utilizando aqui um termo de Jolles ${ }^{21}$, figura de "anti-santo", pautada na violência.

Devemos deixar claro aqui que, mesmo "classificando" essa fase de Matraga como sendo a fase do anti-santo, o nosso personagem não deixa de ser religioso (segundo seus preceitos) em nenhum momento da narrativa. Apesar da contradição, após a reclamação do leiloeiro Tião, pedindo mais respeito pelas coisas santas, é Matraga que consegue acalmar o povo: "Sino e santo não é pagode, povo! Vou no certo... Abre, abre, deixa o Tião passar!". Também , mais adiante, já com o prêmio em mãos (Sariema), ao passar pela porta da igreja "nhô Augusto parou, tirando o chapéu e fazendo o em-nome-do-padre".

Logo, poderíamos acrescentar que esse anti-santo pode assim ser considerado aos olhos do povo do Murici, quando Matraga ainda representa para a população local um coronel defensor de seus interesses, capaz de matar quem ele achar conveniente - tanto assim é que a "gente direita" não participa desse fim de leilão, somente as moças e a "multidão encachaçada de fim de festa".

Mesmo não tendo rédeas, Matraga possui uma posição familiar social, como dissemos inicialmente: sua esposa, Dionora, e filha, Mimita. É pelo discurso indireto livre que o narrador nos traz os pensamentos de Dionora (personagem de raciocínio

\footnotetext{
${ }^{20}$ Os trechos selecionados para citações neste trabalho foram retirados de ROSA, João Guimarães. Sagarana, $20^{\text {a }}$ ed., Rio de Janeiro, José Olympio, 1977.

${ }^{21}$ JOLLES, André. “A Legenda” In : Formas Simples, São Paulo, Editora Cultrix, 1930.
} 
mais sensato e lógico ${ }^{22}$ ) e, através deles, conhecemos um pouco mais desse antisanto.

"Fora assim desde menino, uma meninice à louca e à larga, de filho único de pai pancrácio." (p.329)

Etimologicamente ${ }^{23}$, o termo "pancrácio" significa "exercício de luta a socos". Já, na Legenda Áurea ${ }^{24}$, temos, curiosamente, um São Pancrácio, e, lá, o termo recebe outros sentidos:

"Pancrácio vem de pan, que significa "tudo", de gratus, "agradável", e citius, "depressa", portanto "pronto para ser todo agradável", porque assim o foi desde a juventude. O glossário diz que pancras quer dizer "rapina" e designa também uma pedra de diferentes cores, enquanto pancranarius é "submetido à tortura", e com efeito ele capturou muitas almas cativas, foi submetido ao tormento do açoite e decorado com toda sorte de virtudes". (p.456)

Diante de tais possíveis significações, podemos sublinhar a etimológica, "luta de socos", e uma das legendárias, "submetido à tortura", pois nelas encontramos eco da trajetória de Matraga. Esse "filho de pai pancrácio", além de herdar seu legado financeiro, herdou, digamos, sua tendência à violência e ao fracasso.

Paulo Carneiro Lopes ${ }^{25}$, em sua leitura cristã da novela, diz que, nessa primeira fase de Matraga, estaríamos diante da representação do deus do patriarcalismo que rege conforme o mundo-mercado, ou seja, todas as relações,

\footnotetext{
${ }^{22}$ FRANCO, Maria Sylvia. “A vontade santa” In : Trans/Form/Ação, São Paulo, n.2., 1975.

${ }^{23}$ CUNHA, Antonio Geraldo. Dicionário etimológico Nova Fronteira da Língua Portuguesa. $2^{\mathrm{a}}$ ed. Rio de Janeiro, Nova Fronteira, 1996.

${ }^{24}$ DE VARAZZE, Jacopo. (trad. do latim) Legenda Áurea (Legendae Sanatorum) - vidas de santos, São Paulo, Companhia das Letras, 2003.
} 
mesmo as humanas ou sagradas, baseiam-se no valor da mercadoria - a própria Sariema, a esposa e filha e os capangas poderiam ser as mercadorias de Matraga.

De certa forma, Lopes acerta quando traz a idéia do mundo-mercado em que a matéria concreta é mais valorizada do que as coisas espirituais, pois, nesse início, Matraga não se volta totalmente ao religioso; a religiosidade até aqui parece-nos ser apenas parte obrigatória e oficial da vida pública e não parte íntima de seu ser.

Estabelecendo um paralelo, poderíamos nos lembrar de importantes figuras do meio religioso que também passaram, de uma certa maneira, por essa fase do mundo-mercado. Seriam elas: Santo Agostinho, que se volta, em seu início, à filosofia e, São Francisco, que, mais próximo de Matraga, volta-se ao materialismo de fato - é claro que notamos uma diferença entre os dois religiosos citados e Matraga, ou seja, o nosso personagem, apesar desse afastamento de uma religiosidade, não deixa de ser uma pessoa religiosa; diríamos que o fator religioso nunca desaparece na narrativa, ele terá, sim, momentos de sutil presença (que é o caso da primeira fase de Matraga) e de ápices mais efervecentes (segunda fase) até estabelecer-se numa constante e numa transformação que acompanhará a pessoa de Matraga ${ }^{26}$.

Mas, a semelhança não pode deixar de ser apontada, principalmente em relação a São Francisco - o que vamos analisar mais de perto em texto específico.

Desta primeira fase, ficamos com a imagem do homem do poder local que quer o domínio sobre tudo. Porém, como seu fiel Quim Recadeiro tenta avisar, Matraga inicia sua trajetória de queda - "a casa estava caindo".

“_ Mal em mim não veja, meu patrão Nhô Augusto, mas todos no lugar estão falando que o senhor não possui mais nada, que perdeu suas fazendas e riquezas, e que vai ficar pobre, no já-já... E estão conversando, o Major mais outros grandes, querendo pegar o senhor à traição. Estão espalhando... - (...) - estão dizendo que o senhor nunca respeitou filha dos outros nem mulher

\footnotetext{
${ }^{25}$ LOPES, Paulo César Carneiro. Utopia cristã no sertão mineiro: uma leitura de “A hora e vez de Augusto Matraga” de João Guimarães Rosa. Rio de Janeiro, Vozez, 1997.

${ }^{26}$ Ponto que será melhor estudado mais adiante.
} 
casada, e mais que é que nem cobra má, que quem vê tem de matar por obrigação..." (p.333)

Mesmo com os avisos, Matraga "é couro ainda por curtir" e, ao invés de tirar "umas férias na vida" ${ }^{27}$, nosso personagem vai de encontro à "luta de socos" (uma das significações para a palavra "pancrácio", como vimos) que o faz cair barranco abaixo.

Antes de passarmos à segunda fase de Matraga, é interessante observarmos mais de perto a cena da surra. Antonio Candido ${ }^{28}$, referindo-se ao romance de Rosa, diz haver entre os jagunços um "código estrito", que dita as regras de entrada e de saída dos mesmos, bem como uma espécie de rito de iniciação existente entre eles. Em se tratando de Riobaldo, Candido afirma que será através do pacto com o diabo que o personagem terá a certeza de sua capacidade para liderar o grupo, o que provoca nele uma mudança do ser - no caso de Riobaldo, ele passa a ter a astúcia e a ferocidade que antes lhe faltavam para ocupar tal lugar.

"O iniciado, pela virtude das provas a que se submete, renasce praticamente, havendo um grande número de sociedades que fazem a iniciação consistir na simulação da morte seguida de ressurreição."29

Com a perda de tudo, a surra levada pelos ex-capangas e, principalmente, a marca de ferro em sua pele ${ }^{30}$, Matraga estaria sendo iniciado para um novo nascimento que acarretará também em uma mudança do ser, uma transformação da pessoa de Matraga.

\footnotetext{
${ }^{27}$ Estamos diante dos conselhos da narrativa que permeiam toda a novela - BENJAMIN, Walter. "O Narrador”. ${ }^{28}$ CANDIDO, Antonio. “O homem dos avessos” In : Tese e Antítese. São Paulo, Ed. Nacional, 1971.

${ }^{29}$ CANDIDO, Antonio. Op. cit. p.133.

${ }^{30} \mathrm{O}$ que vamos analisar mais de perto em texto específico.
} 
Ainda observando a cena, vemos que nela, além de seus antigos capangas protagonizarem a ação, é dado destaque à figura do "capiau de testa peluda" que amava a Sariema do leilão da cena primeira da narrativa.

Sua entoada sintetiza o que era agora Augusto Matraga após a surra:

"Sou como a ema,

Que tem penas e não voa..." (p.335)

Outro personagem que também tem a sua desforra dentro de Sagarana é Vinte-e-Um da novela "Duelo". Sua situação é um pouco diferente em relação ao capiauzinho de "A hora e vez": ele havia sido ajudado por Cassiano e, após a morte deste, Vinte-e-Um promete matar Turíbio, o procurado por Cassiano. Portanto, em nossa novela, o capiauzinho tem sua desforra pessoal, pois foi a ele próprio que Matraga havia prejudicado, e, em "Duelo", Vinte-e-Um faz o serviço pelo respeito e admiração que tem pelo mandante do crime. Mas, em todo caso, apontamos aqui a importância dada por Rosa à figura do capiau antes enfraquecido e explorado e depois reconhecido no seu ato de vingança.

Assim, encerramos a primeira fase de Matraga com a cena violenta de sua surra protagonizada pelos antigos capangas e pelo capiauzinho antes humilhado esse seria o ápice do fator violência dentro da novela. 


\section{Segunda Fase}

Damos início à segunda fase de Matraga quando o casal de pretos samaritanos recolhe o corpo maltrapilho caído à porta de sua tapera. Matraga ainda não tem consciência de sua pessoa e seu estado num primeiro momento quando delira em meio às dores da surra, mas, assim que retoma sua idéia, ele deseja viver e pensar, já que agora vê-se só consigo mesmo.

O personagem, nesse início de transformação, toma consciência de sua situação, ou melhor, de sua queda; reconhece que havia "caído num fundo de abismo, em outro mundo distante" (p.338). Esse recomeço é marcado pelo choro solto de desabafo de, digamos, renascimento ${ }^{31}$ - o personagem sente-se desolado, sem proteção e impotente, chegando a chamar pela mãe como uma criança que começa seus primeiros passos, mas ainda sente-se insegura.

Mas, segundo ele, só havia uma única coisa que ainda poderia reconquistar: sua salvação através do perdão dos pecados até ali cometidos. Para tanto, temos, neste momento, a figura do padre como representante oficial do religioso e espécie de conselheiro conhecido do local ${ }^{32}$. Observemos que, para a moderação de seus instintos violentos (típicos, como vimos, na sua primeira fase), o fator religioso atinge agora seu maior momento, pois Matraga vai se pautar no que o padre diz.

“(...)Pois, agora, por diante, cada dia de Deus você deve trabalhar por três, e ajudar os outros, sempre que puder. Modere esse mau gênio: faça de conta que ele é um poldro bravo, e que você é mais mandante do que ele..."

(...)

"Reze e trabalhe, fazendo de conta que esta vida é um dia de capina com sol quente, que às vezes custa muito a passar, mas sempre passa. E você ainda

\footnotetext{
${ }^{31}$ Flaubert conta em Três Contos a história do "São Julião - o Hospitaleiro". Nela, o personagem também passa pelas mesmas fases de Matraga e, na fase de queda, São Julião, ao ouvir a profecia do veado que havia matado (“Maldito!Maldito!Maldito!Um dia, coração feroz, assassinarás teu pai e tua mãe!”), “um desgosto, uma tristeza enorme invadiu-lhe a alma e, pondo as mãos no rosto, chorou copiosamente por longo tempo" (p.60). Após o choro, Julião resolve não ser mais a pessoa que havia sido até aquele momento.
} 
pode ter muito pedaço bom de alegria... Cada um tem a sua hora e a sua vez: você há de ter a sua." (p.339)

Segundo Girard $^{33}$, o religioso é fator fundamental para o equilíbrio das sociedades: o religioso transforma a violência "em uma ameaça transcendente e sempre presente, que exige ser apaziguada tanto por meio de ritos apropriados quanto de uma conduta modesta e prudente" (p.172)

Matraga, seguindo as orientações do padre, vai usar de uma violência interna, digamos, para apaziguar a violência externa: "modere esse mau gênio: faça de conta que ele é um poldro bravo, e que você é mais mandante do que ele..." Nessa luta interna, Matraga inicia sua negação da primeira fase (o anti-santo) com uma intensa mudança no seu comportamento.

Notamos que Matraga tem que sentir-se numa posição ainda superior a algo ("poldro bravo") para que possa distanciar-se de sua antiga fase ou modo de vida, pois, o que lhe fere é não ter mais a sua "homência" e, pelo menos, diante dessa violência transfigurada em bicho bravio, Matraga pode ainda ser o mais mandante.

Outro aspecto apontado por Girard é o perigo que as sociedades vivenciam na falta de uma hierarquia, ou seja, "onde a diferença está ausente, é a violência que ameaça"34. Matraga, ao perder sua posição social, não era mais superior a ninguém, tornando-se igual aos seus capangas, o que caracterizou-se como um momento propício para a queda, e para não haver a "violência recíproca", Matraga tem de dominá-la através também de uma violência interna pautada no religioso - "a religião tem sempre um único objetivo: impedir o retorno da violência recíproca”35

Alguns críticos vêem essa religiosidade de Matraga como sendo apenas cristã. De fato, podemos notar muitos dos princípios cristãos (católico cristão) na novela, mas seria inadequada uma análise baseada apenas no Cristianismo já que a

\footnotetext{
${ }^{32} \mathrm{O}$ padre não só ouve e aconselha Matraga, como também “achou de ensinar à preta um enxofre e tal para o gogo dos frangos, e aconselhou o preto a pincelar água de cal no limoeiro, e a plantar tomateiros e pés de mamão.” (p.339)

${ }^{33}$ GIRARD, René. A violência e o sagrado. São Paulo, Ed. Universidade Estadual Paulista, 1990.

${ }^{34}$ GIRARD, René. Op. cit. p.77.

${ }^{35}$ GIRARD, René. Op. cit. p.75.
} 
novela mostra indícios que comprovam o contrário ${ }^{36}$ - isso ficará mais evidente quando tratarmos da identificação de Matraga com a natureza em texto específico.

Esse início de reconstituição de si mesmo dá-se longe do arraial do Muricí, dáse no sertão (ao Norte). Aqui temos o tema bastante explorado por Rosa: a "travessia humana" - vocábulo que encerra Grande Sertão: Veredas. Matraga resolve distanciar-se do Muricí para rever sua vida. Não só em "A hora e vez" temos essa travessia, mas também em outras novelas de Sagarana como "O Burrinho Pedrês", "A volta do marido pródigo", "Duelo", "Minha gente" e "Conversa de bois". Em todas elas a travessia conota alguma mudança, mas apenas em "A hora e vez" teremos mudança do ser, mudança de valores internos do personagem.

"Para Guimarães Rosa, não há, de um lado, o mundo e, de outro, o homem que o atravessa. Além de viajante, o homem é a viagem - objeto e sujeito da travessia, em cujo processo o mundo se faz." ${ }^{37}$

É nesse sentido - "objeto e sentido da travessia" - que Matraga chega no Povoado do Tombador, negando qualquer lembrança do que havia sido e feito. Seguindo as orientações do padre, ele cansava o corpo e a idéia no trabalho pesado para que as tentações não ocupassem lugar na sua vida. Ficou longe de armas, do fumo, das cantigas, das mulheres, das conversas - a figura do santo começava a delinear-se: "Mas todos gostaram logo dele, porque era meio doido e meio santo; e compreender deixaram para depois" (p.341). A fala do padre virava agora espécie de refrão ("Cada um tem sua hora e a sua vez: você há de ter a sua") repetido sempre que preciso.

Desta forma, o que chamamos aqui de segunda fase caracteriza-se num forte momento do religioso e no início de transformação do anti-santo para o santo que se realizará de fato na terceira fase.

\footnotetext{
${ }^{36}$ Maria Sylvia Franco, em seu ensaio “A Vontade Santa” In : Trans/Form/Ação. SP, no 2, 1975, aponta "uma abjuração da fé cristã” em "A hora e vez”. Segundo ela, Matraga se vale da religiosidade, fazendo o bem ao próximo em benefício de si mesmo e não por amor ao próximo - um dos maiores princípios cristãos.
} 


\section{Terceira Fase}

"Mas, como tudo é mesmo muito pequeno, e o sertão ainda é menor", surge o Tião da Thereza no Povoado do Tombador, mensageiro de más notícias sobre a família de Matraga e seu fiel Quim, e, com esta visita surpresa, inicia-se o que chamamos de terceira fase.

Com a visita, Matraga torna-se outro. As notícias haviam-no perturbado de tal forma que, com aquilo de que antes ele conseguia esquecer-se e afastar-se, agora necessitava conviver diariamente. Como já dissemos, a perda de sua valentia era o que mais Ihe feria ${ }^{38}$, e, com a visita de Tião, Matraga quer voltar a ser quem era.

"E, com a tristeza, uma vontade doente de fazer coisas mal-feitas, uma vontade sem calor no corpo, só pensada: como que, se bebesse e cigarrasse, e ficasse sem trabalhar nem rezar, haveria de recuperar sua força de homem e seu acerto de outro tempo, junto com a pressa das coisas, como os outros sabiam viver." (p.345)

Os pensamentos tentadores, que antes nem surgiam por negar qualquer contato com o que lembrasse o passado, são refreados novamente nas falas do padre e no sentimento de não querer desperdiçar toda a penitência já paga.

"Tenho é de ficar pagando minha culpa, penando aqui mesmo, no sozinho. Já fiz penitência estes anos todos, e não posso ter prejuízo deles! Se eu quisesse esperdiçar essa penitência feita, ficava sem uma coisa e sem outra... Sou um desgraçado, mãe Quitéria, mas o meu dia há-de chegar!... A minha vez..." (p.346)

\footnotetext{
${ }^{37}$ NUNES, Benedito. “A viagem” In : O dorso do tigre, SP, Perspectiva, 1969. (p.179)

${ }^{38}$ Essa perda poderia comprometer, segundo a visão de Matraga, até a sua entrada no céu: "Desonrado, desmerecido, marcado a ferro feito rês, mãe Quitéria, e assim tão mole, tão sem homência, será que eu posso mesmo entrar no céu?!...” (p.345)
} 
Portanto, o desejo de violência, nesta terceira fase, retorna (ainda em pensamento), sendo regulada pelo religioso na idéia do domínio do "poldro bravo" e da chegada de sua libertação. Podemos observar que agora nem a violência e nem o religioso se sobressaem, ou seja, ambos estão juntos em potencialidades iguais - 0 que ocorria contrariamente, como vimos, nas primeira e segunda fases.

O Matraga mítico (santo) começa a se delinear com mais intensidade nesta fase já que podemos observar, de fato, mudança do ser e não apenas negação do passado, pois já não precisava fugir dos velhos hábitos; o sentimento aqui é de alegria intensa do personagem, numa fusão das fases e num entendimento de mundo nunca antes experimentado - convivência dos velhos (o fumo, a preguiça) com os novos valores (o trabalho, a reza).

Porém, Matraga havia de passar por sua maior tentação, tentação corporificada na figura de Joãozinho Bem-Bem, ou seja, o seu desejo de voltar a ter seu poder e seu respeito era apenas pensado, mas, parece que o pensamento toma forma humana. Podíamos esperar que, com uma vida mais regrada e medida, Matraga negasse um tipo como o valente Bem-Bem; todavia, a tentação é colocada para dentro de casa por gentileza e admiração ao hóspede ${ }^{39}$.

Alguns críticos vêem, representado na figura de Bem-Bem o oposto de Matraga, sendo este o representante do Bem e aquele o do Mal - isso explicaria o duelo final da novela. Mas, o que temos na narrativa é a identificação dos dois personagens no respeito de um pelo outro.

"O senhor, mano velho, a modo e coisa que é assim meio diferente, mas eu estou the prestando atenção, este tempo todo, e agora eu acho, pesado e pago, que o senhor é mas é pessoa boa mesmo, por ser. Nossos anjos-daguarda combinaram, e isso para mim é o sinal que serve." (p.354)

Essa identidade dá-se num âmbito de amizade entre dois valentões, entendedores de briga, pois Matraga também possuía sua gente no arraial do Murici.

\footnotetext{
${ }^{39}$ Poderíamos pensar aqui também no mito da hospitalidade ou do bom samaritano.
} 
Logo, o olhar de Bem-Bem para Matraga é não só de reconhecimento de sua bondade, como também de ver naquele homem, agora entregue ao trabalho, um antigo guerrilheiro - "ferrugem em bom ferro".

Os dois personagens, como entendedores de briga, fazem parte do sistema de jagunçagem sertanejo que Rosa quer representar. A complexidade desse sistema é melhor demonstrada e trabalhada em Grande Sertão: Veredas ${ }^{40}$. Lá, os vários bandos que guerreiam entre si trazem toda a engrenagem que conduz as regras do sistema: quem entra, quem sai e quem permanece no bando. O guerrear, no sertão, faz-se necessário.

Matraga, apesar de ter adquirido novos valores em busca de sua salvação, não deixa de reconhecer no amigo sua valentia e sua honra como chefe. Os novos valores, portanto, são cabíveis e exigidos apenas a Matraga - o seu objetivo é individual e extremamente subjetivo; não é exigido de Bem-Bem que ele seja uma pessoa diferente, ele é valorizado no que é.

"O jagunço não é um assassino: ele é um soldado numa guerra; o jagunço não mata: ele guerreia; o jagunço não rouba: ele saqueia e pilha. ${ }^{, 41}$

Essa dúbia imagem do jagunço - a de saqueador, mas não bandido remonta, como já observaram vários críticos, desde Cavalcanti Proença ${ }^{42}$, ao romance de Cavalaria. Mesmo o sistema sertanejo não seguindo "o padrão ideal dos poemas e romances de Cavalaria" ${ }^{43}$, a regra fundamental deve ser seguida: a lealdade - justamente a que foi perdida por Matraga.

Parece-nos que, com a perda de tudo, nosso personagem aproxima-se mais do Cavaleiro medieval no que toca ao fator religioso. Como sabemos, a Cavalaria tinha nos princípios cristãos a sua base e a sua defesa para suas atitudes, e Matraga

\footnotetext{
${ }^{40}$ No romance de Rosa, Joãozinho Bem-Bem reaparece como modelo a ser seguido por Zé Bebelo: "Seu Joãozinho Bem-Bem, o mais bravo de todos, ninguém nunca pôde decifrar como ele por dentro consistia.”

${ }^{41}$ GALVÃO, Walnice Nogueira. As formas do falso. São Paulo, Perspectiva, 1986. p. 18

${ }^{42}$ PROENÇA, Cavalcanti. "Dom Riobaldo do Urucuia, cavaleiro dos campos gerais" In : Trilhas do Grande Sertão.
} 
irá, em sua reconstituição a partir de sua segunda fase, sempre se pautar no religioso para atingir seus objetivos.

E, como nas demais vezes, mesmo essa tentação sendo mais intensa que as outras e, por isso, muito mais chamativa, nosso personagem também resiste à mesma ainda pautado no religioso, porém esse fator parece tonar-se, a partir de agora, apenas um hábito corriqueiro, ao contrário da segunda fase; há uma acomodação da vida, acomodação do religioso e da violência.

"E a força da vida nele latejava, em ondas largas, numa tensão confortante, que era um regresso e um ressurgimento. Assim, sim, que era bom fazer penitência, com a tentação estimulando, com o rasto terreno conquistado, com o perigo e tudo. Nem penou mais em morte, nem em ir para o céu; e mesmo a lembrança de sua desdita e reveses parou de atormentá-lo, como a fome depois de um almoço cheio. Bastava-lhe rezar e agüentar firme, com o diabo ali perto, subjugado e apanhando de rijo, que era um prazer. E somente por hábito, quase, era que ia repetindo:

- Cada um tem a sua hora, e há-de chegar a minha vez!" (grifos meus p.356-357)

Portanto, já podemos enxergar diferenças existentes entre as três fases que estamos tentando delimitar neste trabalho. Temos uma primeira fase com predomínio do anti-santo e de sua violência, uma segunda na qual a violência dá lugar ao fator religioso e uma terceira, a estudada neste texto atual, na qual a violência retorna (ou o desejo dela), mas o religioso também não perde sua importância, havendo, assim, essa acomodação que dissemos entre os dois fatores.

Dessa acomodação, surge a vontade de sair do Povoado do Tombador em busca de sua hora e vez. É relevante apontar que, apesar de parecer que a novela nos traz uma visão bastante fatalista da vida (sinais do destino que haviam de

\footnotetext{
${ }^{43}$ CANDIDO, Antonio. “O homem dos avessos” In : Tese e Antítese. São Paulo, Ed. Nacional, 1971.
} 
ocorrer) ${ }^{44}$, há também a vontade e astúcia de Matraga em todas as suas decisões tomadas: desde a primeira vontade de pensar, quando retomou a consciência após a surra, passando pela vontade de distanciar-se para melhor pensar, pelas negações às tentações, até o desejo de sair, sem planos certos, em busca de sua vez. Assim, na novela, parece haver fatalismo e vontade própria do personagem - "Pro céu eu vou nem que seja a porrete..."

Em seu trajeto de volta, a figura do cego que encontra pelo caminho pode sintetizar essa situação de vontade e destino juntos. O destino de Matraga poderia ser entendido na impossibilidade de enxergar do cego, ou seja, na impossibilidade de prever muitos dos fatos decisivos de sua vida. Ao passo que sua vontade entende-se no desejo do cego de retornar ao seu local de nascimento, pois, de fato, era o que Matraga também queria: ir ao encontro de sua hora e vez segundo a vontade de seu guia.

Além disso, há algumas semelhanças entre os dois personagens: ambos estão retornando ao seu lugar de origem (mesmo Matraga não tendo plena consciência disso) e são guiados segundo a vontade dos animais-guias (jumento de Matraga e o bode do cego).

Quanto aos animais, observamos que um possui uma conotação mais sagrada, devido às passagens bíblicas (jumento que carregou Cristo) e outro mais violenta na figura do bode expiatório (sofrimento). Sabemos que o bode possui várias significações desde a época inicial do Cristianismo, havendo nele a insígnia do judaísmo ${ }^{45}$ e, por conseguinte, uma conotação de exclusão. O jumento sagrado encontra-se, portanto, com o bode condenado nos seus respectivos caminhos de volta ao começo.

Esse caminho de regresso de Matraga ditado por um animal sagrado nos faz lembrar que o primeiro personagem protagonista de Sagarana é um burrinho, em "O burrinho pedrês", cuja função maior, na novela, era salvar a vida de dois vaqueiros da enchente do rio na volta à fazenda do Major Saulo, havendo também, de certa

\footnotetext{
${ }^{44}$ Como por exemplo: o aparecimento do Tião da Thereza no povoado longínquo, o retorno à região do Murici de acordo com as vontades do sagrado animal, o reencontro com Bem-Bem.

${ }^{45}$ Lembrando Gil Vicente, em $O$ Auto da Barca do Inferno, temos a figura do judeu com um bode às costas que é rejeitado por ambas as barcas e condenado a vagar sem destino pelo cais das almas.
} 
forma, um retorno ao início da obra na figura do animal sagrado numa união da primeira com a última narrativa - obra cíclica ${ }^{46}$.

Pensando no objetivo maior de nosso personagem, a salvação, tanto o seu jumento, quanto o burrinho Sete-de-Ouros, possuem a mesma tarefa: guiar a vida de quem está na montaria na direção de sua salvação. Em "O burrinho pedrês", quando os vaqueiros estão de frente com a enchente na dúvida de seguir ou retornar, é deixado para o burrinho a decisão de continuarem ou não a viagem: "O burrinho é quem vai resolver: se ele entrar n'água, os cavalos acompanham, e nós podemos seguir sem susto. Burro não se mete em lugar de onde ele não sabe sair!"(p.61) De fato, o burrinho saíra do lugar alagadiço, mas os demais vaqueiros não, ou seja, o burrinho retorna ao seu coxo (lugar de origem), salvando a vida de Badú e, de carona, a de Francolim também sendo puxado pelo rabo. O jumento de Matraga retorna, segundo sua vontade, ao arraial do Murici (origem), levando nosso personagem ao encontro de sua hora e vez.

É essa travessia de volta, também casual, que proporciona o reencontro com Joãozinho Bem-Bem que, apesar de convidar novamente Matraga para fazer parte do grupo, ocupando o lugar do falecido Juruminho, terá de enfrentar o nosso personagem antes de matar a família do assassino de seu capanga.

Ao observar as súplicas do velho em defesa da família, Matraga, em nome de um senso de justiça adquirido em sua trajetória de reconstrução, parte em sua defesa, desafiando o amigo Joãozinho Bem-Bem.

Não chamaríamos o episódio de duelo por não haver aqui lados opostos; cada um possui sua razão - "Esses homens! Todos puxavam o mundo para si, para o concertar consertado. Mas cada um só vê e entende as coisas dum seu modo." (GS:V) Do ponto de vista de Bem-Bem, aquela era a única maneira de honrar seu jagunço e de honrar sua pessoa e sua autoridade sobre os demais - "Senão, até quem é mais que havia de querer obedecer a um homem que não vinga gente sua, morta de traição?" - , para Matraga, aquilo seria inaceitável, já que o velho estava "pedindo em nome de Nosso Senhor e da Virgem Maria" - "E o que vocês estão querendo fazer em casa dele é coisa que nem Deus não manda e nem o diabo não

\footnotetext{
${ }^{46}$ A questão da marca de ferro é outro elemento que liga as duas narrativas de Sagarana, unindo suas pontas, que
} 
faz!" O desentendimento, então, dá-se entre os objetivos divergentes dos personagens e não na relação dos dois que, como vimos, era amistosa.

A vez de Matraga era a volta de seu reconhecimento, de sua homência, sendo regrada pelo religioso agora. É com a morte que consegue recuperar sua honra: " Perguntem quem é aí que algum dia já ouviu falar no nome de Nhô Augusto Esteves das Pindaíbas!"

De certa forma, a astúcia do "brigador de ofício" retoma seu lugar, porém, a pessoa de Matraga já não é a mesma da primeira fase que analisamos, ou seja, as suas atitudes passam a ser medidas de acordo com novos valores adquiridos - 0 "poldro bravo" continua vivo, mas sob as rédeas de um novo nhô Augusto: o mítico Augusto Matraga na figura do santo.

"As vidas dos santos não ignoram semelhante gênero de variação e não é raro um santo começar a existência como contra-santo. (...) Tais santos talvez sejam, justamente, os mais próximos para o comum dos mortais. ${ }^{\text {"47 }}$

Nessa religiosidade caracterizada também na trajetória do anti-santo para o santo, encontra-se a atualização do mito de regeneração em "A hora e vez" - o herói regenerado de Rosa; o herói dionisíaco de Rosa.

Por caminhos diversos, podemos reconhecer outras narrativas que se encaixariam nesse processo de queda e regeneração, sob a ressalva de que podem não representar exatamente a mudança de ser que temos em "A hora e vez". Para tanto, selecionamos três delas para nossos comentários.

${ }^{47}$ JOLLES, André. “A Legenda” In : Formas Simples, São Paulo, Cultrix, s/d. p. 54 
O próprio Guimarães Rosa registra, num relato breve, a história de Maria Mutema em Grande Sertão: Veredas. Nela, Maria Mutema, após ter matado o marido, tenta livrar-se do pecado cometido indo à igreja para sua confissão; mas, ainda lá, ela causa maldade: mente para o padre dizendo que havia matado o marido por ter se afeiçoado a ele. O padre fica doente de desgosto - falece também. Após um longo tempo sem aparecer na igreja, Maria Mutema surge na missa, em tempo de missão. É impedida pelo sacerdote de adentrar à igreja, mas, mesmo com o impedimento imposto, confessa publicamente todos os seus feitos e pede perdão a todos e a Deus. O povo se comove e junto dela passa a rezar - "Mesmo, pela arrependida humildade que ela principiou, em tão pronunciado sofrer, alguns diziam que Maria Mutema estava ficando santa" (p.197)

Pela breve passagem contada por Jõe Bexiguento para Riobaldo, notamos que para o personagem Maria Mutema também é dado o título de santa após a mudança de sua conduta e do arrependimento de seus atos, mesmo tendo um passado manchado de anti-santa. Mais uma vez a religiosidade é fator fundamental para a virada e reconquista de si perante o povo e Deus.

O mesmo trajeto de queda e ascensão é vivenciado por José na narrativa bíblica. José não terá uma vida de anti-santo obviamente, mas terá de cair literalmente no fundo do poço para depois reerguer-se. Filho mais novo e mais querido de Jacó e Raquel, é vendido pelos irmãos ao comandante da guarda oficial de Faraó, local onde José será mordomo e mais tarde, por armadilha da esposa de Faraó, preso no fundo de um poço, juntamente com outros dois oficiais. Em sua estadia na prisão, José interpreta os sonhos dos companheiros, fato que chega aos ouvidos de Faraó e, desejando saber o significado de um de seus sonhos, retira José da prisão e concede-Ihe a administração do Egito.

Os meios pelos quais houve a queda de José não são os mesmos, evidentemente, dos de Matraga. Como dissemos, José não foi um anti-santo. Estamos diante de um relato bíblico e, segundo Auerbach ${ }^{48}$, temos de levar em consideração o segundo plano presente na narrativa, ou seja, nem tudo na narrativa 
bíblica é explicado com clareza, deixando sempre algo oculto. Portanto, o porquê da queda de José não é explicado e não foi por sua causa ou por seus feitos que ele caiu; o "reflexo da grandeza divina" estaria justamente na trajetória de vida dos personagens bíblicos que passam da humilhação a uma rica evolução ${ }^{49}$.

Outra narrativa, contada por Flaubert ${ }^{50}$, pode também ser um exemplo de renovação de vida. Julião, filho de pais ricos, cresce com todos os requintes necessários e todos os seus desejos realizados "em um castelo, cercado de bosques, na encosta de uma colina". Ao seu nascimento, seus pais tiveram presságios e previsões de desconhecidos acerca do futuro de seu filho. Ainda recémnascido, o narrador o compara ao Menino-Jesus. Cresce freqüentando a igreja assiduamente junto com os pais e é dentro dela que floresce seu verdadeiro ímpeto de vida desregrada, matando um rato que há dias aparecia na parede da igreja. A partir daí, seus dias seriam gastos em matanças de animais que tomaram proporções drásticas. De um veado negro, que com as flechas do matador havia perdido sua família, Julião ouve o que aconteceria futuramente: assassinaria seu pai e sua mãe, o que realmente acontece. Ao final da narrativa, Julião exclui-se do mundo que conhecia, para resignar-se consigo mesmo, trabalhando em prol dos outros ("pôr sua existência a serviço dos outros") na mais profunda miséria. Encontra um homem maltrapilho que, do outro lado da margem do rio $^{51}$, pede-lhe ajuda. Julião o traz até sua tapera onde ele mata sua sede, sua fome e seu frio com o calor do corpo nu de Julião, sendo este arrebatado, segundo a narrativa, aos ceús com "Jesus Nosso Senhor".

Mais semelhante à vida de Matraga, Julião ou São Julião (consta na Lagenda Áurea) percorre o caminho de queda e regeneração também sob os títulos de antisanto para santo, pois, de fato, possuía uma vida sem rumos que encontra sua vez no arrebatamento divino.

\footnotetext{
${ }^{48}$ AUERBACH, Erich. “A cicatriz de Ulisses” In : Mimesis. A representação do realismo na literatura ocidental. São Paulo, Perspectiva, 1971.

${ }^{49}$ AUERBACH, Erich. Op. cit. p.15.

${ }^{50}$ FLAUBERT, Gustave. “ A lenda de São Julião, o Hospitaleiro” In : Três contos, São Paulo, Melhoramentos, 1999.

${ }^{51}$ O que nos lembra a "terceira margem” do rio de Rosa.
} 
Regenerar-se, nessas narrativas, incluindo "A hora e vez", implica o fator religioso como um comportamento mítico também, pois, entendemos que será através dele que os personagens alcançam o objetivo maior: seu antigo reconhecimento. Como observado no capítulo 1, a nossa visão está centrada nesse comportamento mítico, seja através do religioso ou não; assim, em todas essas narrativas, principalmente "A hora e vez", enxergamos uma estrutura mítica (Mito) na atualização do mito de regeneração (mito), conforme distingue Jolles - trajetória de queda e ascensão. 


\subsection{Matraga e a hagiografia de São Francisco de Assis}

Com o objetivo maior de aproximar a trajetória de vida de Augusto Matraga com a de São Francisco, de início, iremos utilizar dois registros biográficos do santo: um autorizado pela igreja contido na Legenda Áurea e outro não autorizado citado por Walnice Galvão ${ }^{52}$ em ensaio dedicado à "A hora e vez".

Legenda Áurea ${ }^{53}$

O registro áureo traz um santo que, na sua juventude, vivia na vaidade e preso ao materialismo do mundo. Esse jovem não chamava-se ainda Francisco; ele ainda era João - o primeiro nome do santo. Quando "o Senhor serviu-se do chicote da enfermidade para corrigi-lo e transformá-lo subitamente em outro homem", João passou a chamar-se Francisco por vários motivos (também relatados na Legenda Áurea num total de sete), entre eles, "indicar os resultados que devia obter, quer dizer, dar a conhecer que ele e seus filhos deviam tornar francos e livres muitos escravos do pecado e do demônio" (p.836).

Em uma das vezes em que estava na igreja a orar, uma imagem de Cristo the disse: "Francisco, vá reconstruir minha casa que, como vê, está toda destruída" (p.837). A partir de então, ele vendeu todas as suas riquezas para dar à igreja; começou a andar com e como os mendigos e misturar-se aos leprosos, fazendo da pobreza a sua senhora.

Muitas outras pessoas o acompanharam nessa nova vida: "Ele escreveu uma regra evangélica para si e para seus irmãos presentes e futuros" (p.838). Também houve vários milagres durante sua vida e após sua morte que são relatados na Legenda Áurea.

\footnotetext{
${ }^{52}$ GALVÃO, Walnice Nogueira. “Matraga: sua marca” In Mitológica rosiana, São Paulo, Ed. Ática, 1978. A fonte biográfica utilizada por Walnice consta em: KAZANTIZAKIS, Nikos. Saint Francis. $2^{\mathrm{a}}$ ed. New York, Ballantine Books Inc., 1969.

${ }^{53}$ DE VARAZZE, Jacopo. Op. cit.
} 
Em uma de suas visões divinas, ele teria adquirido os estigmas conforme os ferimentos do Cristo crucificado, mas as escondia de todos; elas só puderam ser vistas depois de sua morte.

Seu contato íntimo com a natureza também é destacado no relato. Esse contato era estritamente religioso: "chama todos os animais de irmãos" (p.843). Diz um dos acontecimentos: "Ele encontrou uma multidão de aves e saudou-as como criaturas racionais: "Minhas irmãs aves, vocês devem louvar muito seu Criador que as revestiu de penas, que lhes deu asas para voar, que concedeu a vocês a pureza dos ares e que sem pedirem cuida de vocês"54.

Porém, o escravo de Deus - como também é chamado - adoece dos olhos de tanto chorar; passa por uma operação da qual não sentiu dor alguma. A Legenda Áurea não esclarece se o santo curou-se com a intervenção médica ou se piorara, pois, mais ao final da biografia, é dito que Francisco fica profundamente doente (não se sabe de que exatamente). Antes de morrer, "pediu para ser colocado sobre a terra nua, chamou para junto de si todos os irmãos e fazendo a imposição das mãos sobre todos eles abençoou-os, e como na ceia do Senhor deu a cada um deles um pequeno bocado de pão" 55 .

Notamos que o relato autorizado pela igreja prende-se detalhadamente ao seu foco: a santidade de Francisco, relatando em todo o texto muitos milagres concedidos pelo santo. Mas, quanto à sua vida ainda em jovem ou quanto aos seus pais, não temos muitas informações - até mesmo a doença que finaliza a vida de Francisco não é esclarecida. Mesmo assim, podemos apontar semelhanças com a vida de nosso sertanejo Matraga, porém, antes disso, vamos ao relato não autorizado utilizado por Walnice - transcreveremos fielmente o registro feito por Walnice, pois este já está muito bem resumido.

${ }^{54}$ DE VARAZZE, Jacopo. Op. cit. p.844. 
São Francisco, de Kazantzakis (por Walnice Galvão)

"O santo ali aparece como um jovem rico, que passava as noites em farras ou fazendo serenatas para sua namorada, a futura Santa Clara - fundadora da Ordem das Clarissas. Francisco sente, todavia, os opostos que lutam dentro dele: o pai rico e materialista e a mãe devota e pia; ou, diz ele, o embate entre Deus e o Diabo, a luz e a escuridão, o bem e o mal, ou a carne e o espírito. Querendo encontrar Deus, quem o encontra primeiro é o Irmão Leo, que Ihe conta o conselho que recebera de um anacoreta: "Deus é um abismo. Salte! Se não tem coragem, vá para casa, casese e assente". A historinha dá idéia do sentido da santidade como o caminho mais difícil e menos conhecido, desajustador e sem paz de espírito; Deus é algo que se conquista, e com muita dificuldade, para além de imprevistos sofrimentos. Depois de uma doença, em que é atormentado por alucinações, inclusive pela morte que o agarra e the diz que não tem mais tempo para cuidar de se salvar, Francisco volta a si ouvindo uma canção de ninar cantada pela mãe e se sente como se fosse um bebê e tivesse nascido de novo. Pede à mãe que conte como na juventude fugira para seguir os passos do heresiarca Pedro de Lyon, e como a família a impedira e a casara em seguida. Ao ouvi-la, Francisco sente o sangue da mãe nas veias. Logo após, ainda muito doente, tem a primeira visão. Um homem andrajoso, imundo, todo ferido, aparece e Ihe ordena que cuide dele, lave-o e o alimente; ele obedece, e vê que o homem tem marcas de ferro em brasa nas têmporas, chagas nas mãos e nos pés, e na testa uma ferida em forma de cruz. Após ser tratado, vai embora, tendo revelado que ambos são irmãos e a face de um reflete a do outro. Uma vez são, parte também Francisco, não sem antes ter levado em sonhos um empurrão para se apressar; o Irmão Leo viu os hematomas causados pelo golpe no ombro. Ao partir, recomenda à mãe que escreva atrás do tríptico da crucificação que tem em casa: "No dia 24 de setembro de 1206 meu filho Francisco renasceu".

"A primeira visão é uma previsão. São Francisco vai-se tornar um homem andrajoso, imundo, coberto de ferimentos; terá uma moléstia nos olhos que o deixará quase cego, pois de seus olhos purga um matéria sanguinolenta, e como terapia the aplicarão ferro em brasa nas têmporas; morrerá estigmatizado: a imitatio culmina

\footnotetext{
${ }^{55}$ DE VARAZZE, Jacopo. Op. cit. p.846.
} 
numa identitas. A marca em forma de cruz na testa será obtida quando, acometido pela tentação, na pessoa de uma mulher nua a quem chama de Irmã Prostituta e a quem converte, parte para uma alta montanha nevada onde vai enfrentar seus demônios. Despido, flagelando-se, debate-se dias e noites em cima da neve, até cair para frente, desmaiado. E ele sente, assustado, o portento: pergunta ao Irmão Leo, sem tê-la tateado ou visto, qual a forma do ferimento; e é uma cruz; e ele compreende.

"Quase ao término de sua curta vida (1181/82 - 1225/26), consumido pelas privações, São Francisco lembra ao Irmão Leo que o corpo humano, de braços abertos, é uma cruz, e que nessa cruz é que Cristo foi crucificado. Nas experiências místicas, roga a Cristo que Ihe permita sentir no corpo e na alma o sofrimento que ele sentiu na Paixão. Segundo algumas versões, São Francisco já seria estigmatizado nos últimos anos de vida; segundo outras, só no momento da morte.

Entretanto, não se deve esquecer de que, apesar das privações, da estigmatização, da busca deliberada do sofrimento, São Francisco é o santo que deixou a maior lição de felicidade. Aceitava, louvava e proclamava a beleza e o valor de tudo o que existe, cada pássaro, cada estrela, a Lua, o Sol, o fogo. Consta que, antes de morrer, pediu desculpas ao Irmão Corpo por tê-lo mortificado com vistas à salvação da alma. Deve ser lembrada a alegria com que recebeu a chegada da morte e como o espantava que as pessoas presentes chorassem e se lamentassem. Diz-se que, nesse momento, seu rosto resplandecia"56.

De uma maneira diferenciada, a biografia não autorizada de São Francisco traz-nos mais detalhes sobre sua vida, sua conversão, explicando-nos sua trajetória de regeneração com mais clareza que o relato anterior.

\footnotetext{
${ }^{56}$ GALVÃO, Walnice Nogueira. Op. cit. pp.56/57.
} 
As semelhanças entre São Francisco e Augusto Matraga podem ser observadas nos dois registros utilizados aqui. Segundo a Legenda Áurea, Francisco não era o nome de batismo do santo, seu nome real era João. O santo sofre, junto com sua mudança de ser, uma mudança de nome, e nosso personagem rosiano também: de nhô Augusto ao mítico Matraga - curioso é que a narrativa não autorizada não traz essa informação.

Com um novo nome, Francisco inicia sua conversão enfrentando uma doença, da qual se recupera como se estivesse nascendo de novo, ouvindo a canção de ninar de sua mãe - como Matraga, após a surra (que teria o mesmo sentido da doença), recupera-se das dores, ouvindo também as cantigas de fim de tarde da preta samaritana que o socorreu ${ }^{57}$.

Recuperado e decidido a reconstruir a igreja perdida de Cristo, Francisco terá de afastar muitas tentações (relatadas em ambos os registros citados) através do religioso, adquirindo uma nova maneira de ver a vida. Matraga também terá de negar muitos convites e a vontade de voltar a ser o anti-santo do início, possuidor de honra e respeito perante o povo. Sua arma também será o fator religioso.

Abrindo um parênteses neste momento, vale frisar que, como vimos, a religiosidade de Matraga possui um sentido mais subjetivo ou individual, o que contraria a religiosidade de São Francisco, pois o santo terá de recuperar a igreja de Cristo, o que traz um sentido coletivo para essa tarefa; São Francisco vai escrever "uma regra evangélica para si e para seus irmãos presentes e futuros", enquanto Matraga quer a sua salvação da alma, quer o seu lugar no céu.

Para tanto, o caminho da salvação é visto como um caminho árduo e o mais difícil tanto por São Francisco ("Deus é um abismo. Salte! Se não tem coragem, vá para casa, case-se e assente"), como por Matraga ("E só então foi que ele soube de que jeito estava pegado à sua penitência, e entendeu que essa história de se navegar com religião, e de querer tirar sua alma da boca do demônio, era a mesma

\footnotetext{
${ }^{57}$ Procurando um sentido mais profundo do canto, encontramos algumas definições significativas para nosso estudo. Segundo CHEVALIER, Jean e CHEERBRANT, Alain. Dicionário de Símbolos, Rio de Janeiro, Ed. José Olympio, 1995, "o canto é o símbolo da palavra que une a potência criadora à sua criação, (...). Em relação à música - e isso demonstra a Antigüidade da tradição - o canto é primordial: a música, mesmo sagrada, é apenas uma técnica, (...)”. p. 176. O canto, para as duas vidas aqui aproximadas, traz um novo ser no sentido de recomeço, de volta ao princípio (ciclo).
} 
coisa que entrar num brejão, que, para a frente, para trás e para os lados, é sempre dificultoso e atola sempre mais" - p.356)

Para a travessia desse caminho, outro elemento se evidencia: a marca ou, no caso de São Francisco, o estigma. Essa semelhança, juntamente com a mudança de nome, aponta uma espécie de separação do ser, ou seja, uma espécie de diferenciação dessas vidas como uma espécie de escolhidos ou eleitos. ${ }^{58}$.

Suas vidas (a de Matraga e a de São Francisco) se identificam na mudança de ser que há na passagem do anti-santo ao santo, do mundo material ao mundo humilde, conforme a "percisão" e a situação histórica que envolve cada um.

\footnotetext{
${ }^{58}$ Os dois elementos citados neste trecho (a marca e o nome) serão melhor analisados mais adiante.
} 


\subsection{Elementos míticos}

\section{Mudança de nome}

Acompanhando a trajetória de vida de Matraga, notamos que o personagem apresenta uma mudança de nome no decorrer da narrativa. Apesar de termos, nas palavras iniciais da novela, os três nomes de nosso personagem - nhô Augusto, Augusto Esteves e Augusto Matraga -, apenas um predominará no enredo: Augusto.

Antes de observarmos o sentido de cada um deles, interessante é deter-nos nos sentidos de Augusto, presente em todos os nomes de nosso personagem. Paulo Carneiro Lopes ${ }^{59}$, de maneira sucinta, traz alguns desses sentidos:

"Em sua raiz latina aug traz consigo a idéia de aumento, de crescimento. E é desta raiz que nasce auctoritas, de onde vem autoridade e autoritarismo. E é ela também que está na origem do título honorífico Augustus, que, em 27 da era cristã, foi concedido pelo senado ao imperador Otávio, passando a fazer parte de seu nome e dos demais imperadores que o sucederam. Até então, Augustus era título dedicado aos deuses. E, a partir desse momento, o imperador passou a ser considerado uma divindade. Na verdade, foi a partir de então que se consolidou o Império Romano. Todos os poderes civis e religiosos estavam concentrados em suas mãos. Otávio Augusto era o sacerdote supremo, o primeiro cidadão do Estado, chefe do Senado e comandante absoluto do exército. Auguste, o advérbio derivado de augustus, pode ser traduzido por reverentemente ou religiosamente".

De posse desses sentidos, podemos dizer que nosso personagem, em sua fase inicial, era possuidor do autêntico Augustus, a autoridade em pessoa, a de maior poder local. Já a partir de sua segunda fase, após a queda, o Augustus passa

\footnotetext{
${ }^{59}$ LOPES, Paulo César Carneiro. Op. cit. p.89.
} 
a ser quase irônico por não haver mais o status passado. Mas, então por que o nome permanece? No decorrer da novela entendemos o motivo: o personagem passa a ter uma importância diferenciada dessa autoridade sem limites; os novos valores adquiridos (os quais já vimos) faz com que Matraga continue sendo um Augustus, um santo Augusto Matraga na autoridade de novo ser.

Segundo o Dicionário de Símbolos ${ }^{60}$, "para os egípcios da Antigüidade, o nome pessoal é bem mais que um signo de identificação. É uma dimensão do indivíduo". Se pensarmos em Matraga, podemos identificar as dimensões de cada nome, conforme Walnice Galvão ${ }^{61}$ já indicara: nhô Augusto numa dimensão individual ou nome usado em seus relacionamentos; Augusto Esteves numa dimensão social que traz as raízes familiares e daí seu status; e Augusto Matraga numa dimensão mítica com o nome do santo, conforme já considerado pelo povo local.

A dimensão deste último (mítica) vai sendo constituída na própria trajetória de vida do personagem, que somente é nomeado Matraga em dois momentos: no início e no fim da novela, fechando-a ciclicamente. Lembra ainda Walnice Galvão que esse ciclo é comandado também pelo título da novela: "A hora e vez de Augusto Matraga". Então, temos uma narrativa cíclica dentro também de uma obra igualmente cíclica, lembrando a identificação observada anteriormente entre a primeira e a última novelas de Sagarana.

Do nome Matraga temos possíveis significações. Poderíamos lembrar da palavra francesa matraque que significa porrete. Brinquedo ou instrumento religioso que faz barulho, a matraca, ressaltando aqui que ao sonorizarmos o fonema /c/ em lg/, temos o nome grego tragós (bode), o qual, por sua vez, faz menção aos rituais de sacrifício do bode expiatório e à própria presença na palavra tragédia ${ }^{62}$. Indo mais adiante, tragédia possui o significado literal de "canto do bode". "E, originalmente, era com esse canto que se acompanhavam os ritos do sacrifício de um bode nas festas

\footnotetext{
${ }^{60}$ CHEVALIER, Jean et CHEERBRANT, Alain. Op. cit. p. 641

${ }^{61}$ GALVÃO, Walnice Nogueira. Op. cit. p.63.

${ }^{62}$ GALVÃO, Walnice Nogueira. Op. cit. p. 62
} 
de Dionísio"63, o que identificaria Matraga ao mito dionisíaco do renascimento ou, como estamos chamando aqui, de regeneração ${ }^{64}$.

Outro sentido possível para o nome Matraga seria a referência que o mesmo faz às maitacas de presença constante na narrativa. Nesse sentido do som das maitacas, também podemos associar o barulho da casa no enfrentamento final de Augusto Matraga com Joãozinho Bem-Bem:

“_ Êpa! Nomopadrofilhospritossantamêin! Avança, cambada de filhos-da-mãe, que chegou minha vez!..

E a casa matraqueou que nem panela de assar pipocas, escurecida à fumaça dos tiros, (...)" (p.367 - grifos meus)

A respeito da correlação do som da palavra com o som das aves, o Dicionário de Símbolos diz:

"O nome de uma coisa é o som produzido pela ação das forças moventes que o constituem" (p.641)

Assim, Matraga seria o nome ou o som resultante dessa ação interior, ou seja, da transformação do ser pela qual passou, ecoando como pano de fundo o som das aves migratórias, das quais as mais citadas e mais sonoras são as maitacas.

Nessa transformação ou renascimento, Matraga destaca-se dentre as demais pessoas do vilarejo. Levi Strauss, citado por Walnice Galvão ${ }^{65}$, diz que a mudança de nome implica numa separação dos eleitos, principalmente em se tratando dos personagens bíblicos:

\footnotetext{
${ }^{63}$ CHEVALIER, Jean. Op. cit. p.134

${ }^{64}$ É relevante também lembrarmos do encontro de Matraga com o cego guiado por um bode antes de se aproximar do arraial do Muricí em sua travessia de reencontro.

${ }^{65}$ GALVÃO, Walnice Nogueira. Op. cit. p. 52
} 
"Jeová diz a Abrão que ele, mulher e progênie terão favor perpétuo bem como a possessão perpétua da fabulosa terra de Canaã. Muda o nome de Abrão para Abraão e o de Sarai para Sara, a mudança de nome acompanhando toda iniciação e significando uma apartação do comum para pertencer aos eleitos".

Outros são os exemplos bíblicos como o neto de Abraão, Jacó que se chamará Israel; Saulo se tornará Paulo; Simão que terá outro nome acrescentado a esse: Cefas que significa Pedro, e, não como personagem bíblico, mas como religioso, já citado anteriormente, temos João que virá a ser Francisco.

Como sinal de mudança, em todos esses casos, o nome passa a ser diferenciado do que já existia ${ }^{66}$, passa a ser mítico.

${ }^{66}$ Outro exemplo que traz a mudança de nome junto da mudança de ser de seu possuidor é notado em Berlin Alexanderplatz, de Döblin. Seu herói, Franz Biberkopf recupera-se de um vida marginal, passando por um 


\section{A marca de ferro}

Com o objetivo maior de estudar os significados embutidos na marca de Matraga, Walnice Galvão inicia seu ensaio voltando o olhar à Antigüidade Clássica na qual iniciou-se um interesse maior pelo estudo de emblemas - "muito da literatura de ficção, em poesia ou em prosa, fica indecifrável se não se recorre a essa simbologia tão conhecida durante tantos séculos". 67

Concentrando-se na marca de ferro de Matraga - "um triângulo inscrito numa circunferência" -, Walnice vai analisar "o significado do triângulo e o significado da circunferência, e o significado da relação entre ambos". 68

O triângulo da marca - mínimo polígono possível dentro da geometria - teria um significado cristão em um dos maiores dogmas da Igreja: a união das figuras do Pai, do Filho e do Espírito Santo, daí a repetição do número três na Liturgia. Walnice lembra ainda que "o dogma trinitário originou-se do dogma cristológico. Jesus Cristo é a única revelação de Deus na história, e aos que desejam identificar-se com ele só resta a imitação". (p.45) E desde a Idade Média os assuntos sagrados já eram organizados inclusive em Ordens; a arte e a Liturgia andavam juntas "e os signos rigidamente predeterminados".

Portanto, o número três consagrou-se, com o tempo, como o número que "designa todas as coisas espirituais", mesmo antes do cristianismo nas religiões pagãs. Deus teria, assim, marcado toda a sua criação numa natureza tríplice.

"Interessa reter que, seja nos mitos pagãos, seja no cristianismo, "o ser é portador da marca divina", e essa marca é triádica". (p.46)

A circunferência, por sua vez, designa a forma geométrica mais simples e o polígono mais complexo, "dado que constituído do maior número possível de lados".

\footnotetext{
"processo de maturação”, e recebe outro nome: Franz Karl, ascendendo, como diz Walter Benjamin (“A crise do romance”), "ao céu das personagens romanescas".

${ }^{67}$ GALVÃO, Walnice Nogueira. Op. cit. p.43
} 
Pode trazer também a idéia de movimento repetido, ou seja, de retorno ao ponto de partida que também será ponto de chegada.

O emblema completo teria ligação íntima com o destino de Matraga já que o mesmo foi marcado na carne; algo que levará por toda a vida. Walnice lembra da primeira marca bíblica em Caim e a conhecida marca ou cicatriz de Ulisses pela qual é reconhecido em seu retorno ao lar.

A marca na carne também é sinal de eleição quando se trata de uma "marca de pertença". Mas, pode ser considerada também uma "marca ignominiosa", de desonra, cujo portador é criminoso ou escravo. Cristo teria tido primeiramente uma marca de desonra, ignominiosa aos olhos do povo (ele foi crucificado como criminoso), mas transformou essa mesma marca em marca de pertença, de eleito, o que, segundo Walnice, acontece também com Matraga. ${ }^{69}$

Sua via-crucis identifica-se, como vimos, com a vida de São Francisco - o primeiro estigmatizado do catolicismo. Como dito, a marca triádica vem do desejo de imitação de Cristo. E é o mesmo desejo de São Francisco - da imitatio a identitas.

Quanto a Matraga, vemos que, no desejo de salvação da alma, sua morte assemelha-se à morte expiatória de Cristo, substituindo a morte do velho em nome de novos valores.

"Certamente, ele tomou sobre si as nossas enfermidades e as nossas dores levou sobre si; e nós o reputávamos por aflito, ferido de Deus e oprimido.

Mas ele foi traspassado pelas nossas transgressões e moído pelas nossas iniqüidades; o castigo que nos traz a paz estava sobre ele, e pelas suas pisaduras fomos sarados". (Is 53: 4-5)

A paz, de certa forma, é estabelecida no povoado após o confronto final entre Matraga e Bem-Bem:

\footnotetext{
${ }^{68}$ GALVÃO, Walnice Nogueira. Op. cit. p.43
}

${ }^{69}$ GALVÃO, Walnice Nogueira. Op. cit. p.54 
"E o velho choroso exclamava:

_ Traz meus filhos, para agradecerem a ele, para beijarem os pés dele!... Não deixem este santo morrer assim..." (p.370)

$\mathrm{Na}$ análise de Walnice, Matraga é um "santo guerreiro", "e é como guerreiro que irá se tornar santo". Ao contrário do "santo asceta", Matraga, não contrariando sua índole, conquista a santidade guerreando. E ele só decifrará seu destino se também puder decifrar sua marca que encerra a "igualdade na oposição e oposição na igualdade", pois as figuras que compõem o símbolo são iguais por serem figuras básicas da geometria e são opostas quanto ao número de lados que as constituem: triângulo, possuindo o número mínimo para a composição de um polígono e círculo, possuindo um número infinito de lados.

E qual seria o significado da marca? Para Walnice, "a marca de Matraga seria uma mandala cristã, indicando um processo de integração da personalidade e de realização pessoal no mundo, ratificação como assinatura de Deus" (p.61), determinada "por um compasso ao mesmo tempo ternário e circular" (p.62). Ternário nos vários índices do número três na novela (os três nomes, os três lugares de sua travessia: Murici, Povoado do Tombador e Rala-Coco, vivência em trios: mulher e filha, casal de pretos, velho e Bem-Bem) e circular pela própria circularidade da narrativa (como dito, a presença do nome Matraga no início e no fim, sua travessia que retorna ao ponto de partida e, Walnice lembra que "no momento em que se inicia o relato, o relatado já ocorreu há muito tempo e está fechado em sua perfeição de acontecido" (p.62), ou seja, a novela inicia pelo fim da mesma).

Dessa forma, a marca de Matraga é uma marca de mudança ou que "vai provocar a mudança" de ser do personagem.

Outro personagem de Sagarana marcado a ferro (em forma de coração) é o já citado burrinho Sete-de-Ouros de "O Burrinho Pedrês". Mas, lá a marca é em animal de propriedade particular que o coloca no lugar de burro de carga apenas, apesar de ter salvado a vida do vaqueiro Badú. 
Então, a igualdade dos animais de tarefas semelhantes (Sete-de-Ouros e o jumento de Matraga) e a presença de marca de ferro (que inverte sua posição em "A hora e vez", sendo fixada "no homem humano") unem as novelas. Claro que essa circularidade de Sagarana mereceria estudo à parte para que fossem determinados os limites desses encontros e seus possíveis significados, o que não constitui objetivo principal deste trabalho.

Em suma, além do nome já visto, ficamos com mais um elemento mítico, a marca de ferro, que, como vimos na análise de Walnice Galvão, determina os passos de nosso personagem, o qual imita a vida de Cristo, o modelo maior do Cristianismo, reforçando a estrutura mítica que estamos tentando delinear na novela. 


\section{A identificação com a natureza}

Dois anos após o lançamento de Grande Sertão: Veredas, Proença ${ }^{70}$ já tratava, em seu livro, da questão do mito no romance de Rosa. Em sua visão, o mítico está representado pela natureza sertaneja (no sertão fatal e misterioso; nos rios, principalmente o Urucuia; na vegetação, como o Buriti, que propicia momentos de "remansos" na narrativa) que acompanha, em sua mobilidade, as fases da vida dos personagens.

Para o crítico, o homem sertanejo, conhecedor da natureza e seus fenômenos, está ligado às forças naturais do sertão. E é exatamente no sertão que Matraga renasce também para o mundo natural ao seu redor - Antonio Candido já apontava esse despertar primaveril existente na novela, em seu ensaio "Sagarana", quando diz que "em "A hora e vez de Augusto Matraga" há uma certa entrada de primavera - verdadeiro Sacre du Printemps - em que a natureza nos comunica sentimento quase inefável, germinal e religioso"71

Os primeiros sons apreciados por nosso personagem serão os das criações do casal de pretos, logo após a queda no barranco:

"Mas, de tardinha, chegou a hora da tristeza; com grunhidos de porcos, ouvidos através das tendas da parede, e os ruflos das galinhas, procurando poleiro nos galhos, (...)" (p.337 - grifos meus)

Também os sapos são ouvidos - "os sons dos primeiros sapos" encontram-se registrados desde a epígrafe da novela no provérbio capiau: "sapo não pula por boniteza, mas porém por percisão".

\footnotetext{
${ }^{70}$ PROENÇA, Cavalcante. "Plano Mítico” In Trilhas do Grande Sertão, Rio de Janeiro, MEC, 1958.

${ }^{71}$ CANDIDO, Antonio. "Sagarana” In : COUTINHO, Eduardo (org). Guimarães Rosa. Fortuna Crítica, Rio de Janeiro, Civilização Brasileira, 1983. (p.246)
} 
Aliás, pensando na trajetória de nosso personagem, sua atitude de pular barranco abaixo deu-se, de fato, por "percisão". Então, começamos, de certa forma, a aproximar a figura do sapo que surgirá em outra citação com a figura de Matraga.

Como dizíamos, é na ida para o sertão (travessia feita com o casal de pretos a fim de que recuperasse sua identidade) que Matraga se aproximará ou se identificará com a natureza e suas forças. No caminho de ida o narrador dá destaque aos lugares deixados para trás e aos lugares nos quais Matraga e seus pais adotivos tiveram de atravessar, como o Rio das Rãs e o Rio do Sapo - repetindo pela segunda vez a figura do animal.

A descrição da viagem passa ao leitor uma sensação de vista corrida da janela de um trem, pela qual o que é de mais marcante fica gravado na mente.

Já nesse caminho temos a presença das aves, não ainda das maitacas, mas das garças, pois Matraga atravessava tudo "sob o vôo das garças", conforme ilustração de Poty na página 342 da edição de Sagarana aqui utilizada.

Até aqui vemos que a ligação de Matraga com a natureza intensifica-se já a partir do momento em que resolve seguir outros rumos ou seguir o ditado antes não observado pelo personagem: "tirar férias da vida".

O trabalho que se dispõe a fazer exaustivamente aos outros no Povoado do Tombador é comparado pelo narrador com o trabalho exercido pelos animais na sua luta pela sobrevivência diária:

“"(...), porquanto ele não tinha tentações, nada desejava, cansava o corpo no pesado e dava rezas para a sua alma, tudo isso sem esforço nenhum, como os cupins que levantam no pasto murundús vermelhos, ou como os tico-ticos, que penam sem cessar para levar comida ao filhote de pássaro-preto - bico aberto, no alto do mamoeiro, a pedir mais." (p.343)

Essa sobrevivência também era, agora, natural a Matraga, e suas ações passam a aproximar-se cada vez mais das ações naturais do mundo. Benedito 
Nunes $^{72}$ diz, em relação a Grande Sertão, que a natureza do sertão é animada, participante da narrativa, ou seja, tudo nela é significativo por fazer parte integrante da narrativa: "as mudanças da natureza acompanham as metamorfoses da narrativa" (p.35).

Notemos que na primeira fase de Matraga, na qual regia o anti-santo em sua violência, a natureza não é enfatizada pelo narrador como o é a partir de sua segunda fase. Isso denota que a decisão de Matraga em mudar ou regenerar-se poderia estar ligada às forças naturais ${ }^{73}$.

Encontramos dois grandes momentos dessas forças que influenciariam os sentimentos ou modo de ser de Matraga: a "chegada do tempo das águas", logo após a confissão do personagem feita aos "pais", e a conseqüente estiagem, quando as chuvas cessam, depois do primeiro encontro com Bem-Bem.

No primeiro momento, constam vários índices que constróem juntos a idéia de acontecimentos novos surgindo:

"Até que, pouco a pouco, devagarinho, imperceptível, alguma cousa pegou a querer voltar para ele, a crescer-Ihe do fundo para fora, sorrateira como a chegada do tempo das águas, que vinha vindo paralela: com o calor dos dias aumentando, e os dias cada vez maiores, e o joão-de-barro construindo casa nova, e as sementinhas, que hibernavam na poeira, esperando na poeira, em misteriosas incubações. (...). E as mariposas e os cupins-de-asas vinham voar ao redor da lamparina... Círculo rodeando a lua cheia, sem se encostar... E começaram os cantos. Primeiro, os sapos: - "Sapo na seca coaxando, chuva beirando", mãe Quitéria!... Apareceu uma jia na horta, e pererecas dentro de casa, pelas paredes... E os escorpiões e as minhocas pulavam no terreiro,

\footnotetext{
${ }^{72}$ NUNES, Benedito. “O mito em Grande Sertão: Veredas” in : Revista Scripta.

${ }^{73}$ Poderíamos pensar no mito da Primavera ou de Deméter. Tida como a deusa do trigo e da terra cultivada, aparece na mitologia ligada à sua filha, Perséfone. Esta foi capturada por Hades (deus do inferno) que havia se encantado pela deusa. Deméter, desesperada, resolveu não mais fazer germinar os grãos na terra. Como solução para o problema, Zeus decidiu que Perséfone viveria uma parte do ano na terra com a mãe e a outra nas profundezas com Hades, pois já não podia sair definitivamente do inferno por ter quebrado o jejum deste lugar. Assim, teríamos a Primavera, com as primeiras sementes, e o Inverno, com o começo das colheitas - ciclo natural de renovação.
} 
perseguidos pela correição das lava-pés, em préstitos atarefados e compridos... No céu sul, houve nuvens maiores, mais escuras. Aí, o peixe-frito pegou a cantar de noite. A casca de lua, de bico para baixo, "despejando"... Um vento frio, no fim do calor do dia... Na orilha do atoleiro, a saracura fêmea gritou, pedindo três potes, três potes, três potes para apanhar água... Choveu." (p.347 - grifos meus)

Notamos que a "casa nova" do joão-de-barro e as "sementinhas' em "incubações" são como Matraga: renascendo, ressurgindo. E todos os outros animais ou insetos citados provêm das chuvas ou do "tempo das águas" que tudo renova como o círculo formado pelas mariposas e os cupins-de-asas em torno da lamparina.

Os sapos são citados novamente, como dissemos. Vejamos alguns significados encontrados na figura do animal. Conforme o Dicionário de Símbolos ${ }^{74}$, são conferidos vários sentidos ao animal desde o mais conhecido entre nossa cultura ("anunciador da chuva"), até os mais diversificados ("símbolo de sucesso" para os vietnamitas, "atributo dos mortos" para os egípcios, "símbolo de luxúria" para os gregos e posição importante "nas tradições européias de magia e de feitiçaria"). Câmara Cascudo ${ }^{75}$ resume a figura do sapo como sendo "um elemento de representação cômica e, às vezes, de astúcia solerte e vitoriosa" desde as "fábulas de Esopo aos contos populares africanos, oceânicos, asiáticos ou europeus"76

Identificando Matraga com a imagem do sapo desde o provérbio inicial citado, o que temos ao final é, de fato, um Matraga vitorioso, de objetivos alcançados, não deixando de ser, ao mesmo tempo, uma figura cômica. Esse cômico, que parece permear a narrativa, pode ser notado em uma das falas-refrão do personagem: "Pro céu eu vou nem que seja a porrete..." Além do cômico, ela traz consigo toda uma maneira de pensar de Matraga como um típico guerreiro sertanejo que, mesmo reconstruindo sua trajetória, não contradiz sua índole, mantendo os valores velhos junto com os novos.

\footnotetext{
${ }^{74}$ CHEVALIER, Jean. Op. cit.

${ }^{75}$ CASCUDO, Luiz da Câmara. Dicionário do Folclore Brasileiro, São Paulo, Global Ed., 2001.

${ }^{76}$ CASCUDO, Luiz da Câmara. Op. cit. p.620.
} 
Assim, nesse primeiro momento, a idéia da renovação da natureza pelas águas identifica-se com o novo Matraga em surgimento, principalmente na mudança de comportamento dos animais.

A estiagem já anuncia um Matraga mudado ou transformado por completo (lembrando a terceira fase que analisamos).

"Mas, afinal, as chuvas cessaram, e deu uma manhã em que Nhô Augusto saiu para o terreiro e desconheceu o mundo: um sol, talqualzinho a bola de enxofre do fundo do pote, marinhava céu acima, num azul de água sem praias, com luz jogada de um para o outro lado, e um desperdício de verdes cá em baixo - a manhã mais bonita que ele já pudera ver." (p.357)

Apesar de usar o termo "desconhecer o mundo", Rosa aproxima o personagem intimamente com toda a natureza poeticamente descrita. Maria Sylvia Franco $^{77}$ diz, em ensaio já citado, que o renascimento de Matraga dá-se tão intensamente que ele se desvia de Deus e "chega a sentir o sopro do panteísmo". A identificação com as forças naturais ou essa descoberta do mundo sensível estabelece-se sem intermediações. Lembremos que, na terceira fase de Matraga, os fatores violência e religião sofrem uma acomodação; não são tão influentes nas decisões de Matraga ou na sua maneira de ver o mundo.

Portanto, quando dissemos que não é cabível identificar a religiosidade presente no nosso personagem como sendo apenas cristã, estávamos nos referindo, mais especificamente, a essa abertura do personagem ao todo exterior e interior; Matraga encontra-se em sua maior totalidade como ser regenerado e também na totalidade do fator natural, concordando aqui com a colocação de Maria Sylvia.

Remetendo-nos novamente ao nome de Matraga, lembramo-nos de sua possível identificação com as maitacas migratórias como na passagem abaixo: 
“De repente, na altura, a manhã gargalhou: um bando de maitacas passava, tinindo guizos, partindo vidros, estralejando de rir. E outro. Mais outro. E ainda outro, mais baixo, com as maitacas verdinhas, grilhantes, gralhantes, incapazes de acertarem as vozes na disciplina de um coro.

Depois, um grupo verde-azulado, mais sóbrio de gritos e em fileiras mais juntas.

_ Uai! Até as maracanãs!

(...)

E agora os periquitos, (...).

Mas o que não se interrompia era o trânsito das gárrulas maitacas." (p. 357 grifos meus)

Será essa repetição das maitacas no texto que fará a associação delas com o nome Matraga, como um prévio eco do mesmo. O rumo delas é questionado pelo personagem: "Já devem de estar longe daqui..." E o questionamento vem na voz do narrador: "Longe, onde?" Parece-nos que o uso do advérbio "onde" é proposital como se a pergunta fosse: "onde terei minha vez?" Com o eco das maitacas e seu instinto itinerante como pano de fundo, Matraga decide tomar outros rumos agora mais certeiros do que a sua retirada para o sertão porque a sua vez havia de chegar "em outras partes", mas na mesma "direção das maitacas viajoras".

A ligação entre as aves e a saída de Matraga do Povoado do Tombador parece-nos bastante possível pelos próprios indícios vistos na narrativa: atitudes instigadas por forças naturais do mundo exterior somadas às mudanças ocorridas internamente, como podemos observar no trecho:

“_ Espera o fim das chuvas, meu filho! Espera a vazante..

_ Não posso, mãe Quitéria. Quando coração está mandando, todo tempo é tempo!..." (p.358)

\footnotetext{
${ }^{77}$ FRANCO, Maria Sylvia. Op. cit. p.111.
} 
Nesse caminho de retorno, não só o amanhecer é contemplado por Matraga, como também o poente: "Pela primeira vez na sua vida, se extasiou com as pinturas do poente, com os três coqueiros subindo da linha da montanha para se recortarem num fundo alaranjado, onde, na descida do sol, muitas nuvens pegam fogo." (360/361)

Poderíamos pensar nas três fases de Matraga, nessa passagem, relacionando-se com os três coqueiros no fundo da paisagem contemplada pelo personagem.

Certo é que o vocábulo "contemplar" aparece um pouco antes do trecho citado, quando Matraga precisa escapar de uma boiada de duas mil cabeças, ficando "a contemplar do alto", "a meia-encosta", os animais e os vaqueiros. Logo depois, ele se extasia, como diz o texto, com a paisagem dos três coqueiros tendo como pano de fundo o poente alaranjado.

Pensando no conceito do verbo "contemplar", segundo Aristóteles ${ }^{78}$, teríamos uma atividade desinteressada e a que supera todas as outras atividades humanas por ser uma atividade intelectual e, por isso, a que traz a felicidade.

"Mas se a felicidade consiste na atividade conforme à excelência, é razoável que ela seja uma atividade conforme à mais alta de todas as formas de excelência, e esta será a excelência da melhor parte de cada um de nós. Se esta parte melhor é o intelecto, ou qualquer outra parte considerada naturalmente dominante em nós e que nos dirige e tem o conhecimento das coisas nobilitantes e divinas, se ela mesma é divina ou somente a parte mais divina existente em nós, então sua atividade conforme à espécie de excelência que the é pertinente será a felicidade perfeita. Já dissemos que esta atividade é contemplativa." (1177a - 1178a, p.201/203)

Quando Matraga passa a identificar-se com a natureza e, talvez por esse motivo, a contemplar essa totalidade do exterior que o envolve, a narrativa transmite

\footnotetext{
${ }^{78}$ ARISTÓTELES. Ética a Nicômacos.
} 
ao leitor justamente o sentimento de felicidade do personagem que, como ser regenerado, está prestes a alcançar sua hora e vez. 


\section{MATRAGA E O BRASIL DA ÉPOCA}

Retomando a frase do mitólogo Cornford, citada por Vernant, que diz: "o mito é racionalizado", podemos reconhecer na atualização do mito de regeneração existente em "A hora e vez" uma racionalização do mesmo quando enxergamos, nessa estrutura mítica, aspectos do Brasil da época.

A análise mais precisa e mais extensa de "A hora e vez" centrou-se, neste trabalho até agora, na questão da atualização do mito de regeneração na imagem do renascido e mítico Matraga, seguindo a teoria de Jolles já colocada no primeiro capítulo: temos a forma simples Mito (no reconhecimento da narrativa como sendo estruturalmente mítica) em suas respectivas atualizações.

Todavia, essas reelaborações podem refletir também aspectos históricosociais de suas respectivas épocas. De fato, a fortuna crítica rosiana já tem se debruçado sobre essa "tentativa de identificar um método de ver o país"79 presente na obra de Rosa. E nossa novela em questão pode trazer também sua contribuição para a formação dessa visão do "Brasil de Rosa"80.

Portanto, ao reelaborar o mito, Rosa também traz, nas entrelinhas, reflexões particulares sobre a sociedade brasileira - o geral/universal (mito) e o particular/regional (história).

“(...) homens e mulheres, sempre que dão um passo decisivo à frente, revisam sua mitologia e fazem com que ela trate das novas condições." $" 1$

\footnotetext{
${ }^{79}$ STARLING, Heloísa M. Murgel. "O sentido do moderno no Brasil de João Guimarães Rosa - veredas de política e ficção” In : Revista Scripta, v.2, n.3, Belo Horizonte, PUCMinas, 2º sem. 1998.

${ }^{80}$ Fazemos uso do título do livro de Luiz Roncari. O Brasil de Rosa, São Paulo, Ed. Unesp, 2004.

${ }^{81}$ ARMSTRONG, Karen. Op. cit. p.16.
} 
De acordo com as diferentes épocas vividas, fez-se necessária a reinterpretação mítica ou a mudança da forma de pensar o mundo num processo natural de desenvolvimento empírico pelo qual o ser humano passou.

Essas "novas condições", portanto, refletem os conflitos histórico-sociais da época, o que faz o mito ser, de certa forma, racionalizado quando traz questionamentos profundos sobre o homem em seu convívio social. Portanto, o mito permanece, mesmo após seu declínio, como modelo para o comportamento humano, mas, agora, refletindo e discutindo questões sociais complexas que são fruto das primeiras articulações filosóficas da Grécia Antiga - o mito continua respondendo às necessidades humanas em suas diversas atualizações e em sua racionalização.

Mais especificamente, em nosso caso, o processo e as transformações pelas quais passa o mítico Augusto Matraga denunciam um Brasil bastante misturado e complexo.

O ano de publicação de Sagarana (1946) corresponde a uma fase de transição na vida política do Brasil e por isso de incertezas e indefinição de rumos, além das várias tentativas de democratização da sociedade brasileira com a Constituição de 1945 ( $5^{\mathrm{a}}$ brasileira e $4^{\mathrm{a}}$ da República) que trazia em seus artigos e leis um tom mais liberal do que as anteriores devido à derrota dos regimes ditatoriais pelo mundo.

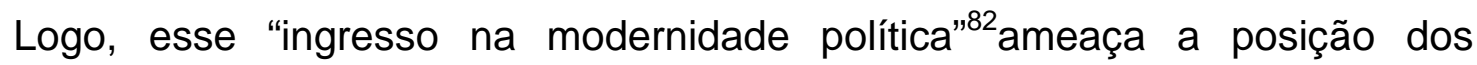
coronéis rurais, controladores do poder local, principalmente do sertão brasileiro. Mas, como veremos na denúncia feita por Rosa, em "A hora e vez", esse sistema local e já de tradição não se abalaria integralmente.

Para notarmos mais claramente como essa problemática do Coronelismo pode estar presente em "A hora e vez", estabelecemos dois momentos na narrativa.

\footnotetext{
${ }^{82}$ STARLING, Heloísa M. Murgel. Op. cit.
} 


\subsection{Nhô Augusto: afirmação do Coronelismo local}

"Sertão. O senhor sabe: sertão é onde manda quem é forte, com as astúcias.

Deus mesmo quando vier, que venha armado!"

Grande Sertão: Veredas

Chamamos de Coronelismo o que Victor Nunes Leal ${ }^{83}$ define como "um compromisso, uma troca de proveitos entre o poder público, progressivamente fortalecido, e a decadente influência social dos chefes locais, notadamente dos senhores de terras"; ou seja, um sistema local e de poder informal que predominou na realidade sertaneja do Brasil com a figura do proprietário de terras, juntamente com seus agregados e seu bando armado para a defesa pessoal.

O poder público valeu-se desse poder concentrado nas mãos da minoria proprietária de terras que comandava a massa de manobra composta pelos homens livres, mas sem posses. Os grandes proprietários ou coronéis, querendo figurar como autoridade do governo em suas áreas, formavam ou contratavam bandos armados para a defesa ou a imposição de suas decisões em conflitos de terra e gado. O compromisso dos capangas para com o senhor estava baseado na defesa do proprietário e seus bens em todas as ocasiões, ou seja, esses trabalhadores "são levados à dependência absoluta dos homens de posse" ${ }^{\text {"34 }}$

No nosso caso, nhô Augusto, o primeiro Augusto da narrativa, regido, como vimos, pela violência do anti-santo, faz parte do Coronelismo vigente no Nordeste brasileiro e, por isso, pode representá-lo, já que nosso personagem, em sua primeira fase, detém o poder local. Como chefe de um bando armado, nhô Augusto - no próprio tratamento dado a Augusto pelo povo e por seus "cacundeiros", temos um sinal de respeito perante sua pessoa; ele é o senhor - figura-se como herói e detentor do poder não só por seus capangas, como também pelos demais homens livres do Povoado do Muricí.

\footnotetext{
${ }^{83}$ LEAL, Victor Nunes. "Indicações sobre a estrutura e o processo do "Coronelismo”” In : Coroneslimo, enxada e voto, Rio de Janeiro, Ed. Nova Fronteira, 1997. (p.40)

${ }^{84}$ ANDRADE, Fábio de Souza. "Leilão divino, tribunal jagunço" In : Literatura e Sociedade/ Departamento de Teoria Literária e Literatura Comparada/ Faculdade de Filosofia, Letras e Ciências Humanas/ Universidade de São Paulo - n. 6 (2002) - . - São Paulo: USP/FFLC/DTLLC, 2002.
} 
O poder que exercia era local e, por isso, informal. O título de Coronel é dado no parágrafo de abertura da novela, revelando suas raízes familiares.

"Matraga não é Matraga, não é nada. Matraga é Esteves. Augusto Esteves, filho do Coronel Afonsão Esteves, das Pindaíbas e do Sacodo-Embira." (grifos meus - p.324)

Portanto, nhô Augusto, apesar de não ser tratado como Coronel durante a narrativa, é filho de um, logo herda a mesma posição como senhor de terras, propriedades e homens.

Seu círculo de convívio social girava entre a família oficial (esposa, Dionóra, e filha, Mimita), os capangas (num total de quatro) e o empregado mais fiel (Quim Recadeiro). Porém, sua vida de fato era ocupada "com os capangas, com mulheres perdidas, com o que houvesse de pior". Essa sina frouxa e torta revela uma volubilidade na estrutura familiar, que também é característica da sociedade brasileira.

Segundo Luiz Roncari ${ }^{85}$, essa volubilidade se caracterizaria na presença das três mulheres na vida do homem ou três formas de prazer; a oficial (para a prole), a amante (para o sexo) e o amigo (para o amor do convívio social). No nosso caso, nhô Augusto possuiria Dionóra, suas mulheres à toa e seus capangas - costume também herdado do pai, pois "pai era como que nhô Augusto não tivesse..."

Dentro desse meio social, Maria Sylvia Franco ${ }^{86}$ faz uma análise comparativa entre Augusto, Dionóra e Quim sob o ponto de vista da condição humana. Quim, em um dos pólos, representaria a anulação de si mesmo em detrimento do patrão; Dionóra, no meio termo, seria "a mais real das personagens", a "fraca-forte, submissa-voluntariosa, desamparada-independete", enfim, a "mais próxima da

\footnotetext{
${ }^{85}$ RONCARI, Luiz. “Irmão Lélio, irmã Lina: incesto e milagre na "Ilha do Pinhém”” In : Estudos Avançados, São Paulo, n.42, v. 15, 2001.

${ }^{86}$ FRANCO, Maria Sylvia. Op. cit. p.98.
} 
condição humana" ${ }^{37}$; e Augusto, no outro pólo, seria a representação da "posse máxima de si mesmo", indo de encontro ao sentido do Augustus.

Como um típico Coronel, Augusto possuía seus capangas, os quais the deviam proteção em todo momento preciso. Esses são os chamados homens pobres livres - "aqueles que não são nem senhores nem escravos"88. Assim, Walnice Galvão define-os:

"Livre, e por isso mesmo dependente. Sem ter nada de seu, e por isso mesmo servidor pessoal de quem tem. Inconsciente de seu destino, e por isso mesmo tendo seu destino totalmente determinado por outrem. Sem nada a defender, e por isso mesmo usado para defender causas alheias. Avulso e móvel, e por isso mesmo chefiado autoritariamente e fixado em sua posição de instrumento. Posto em disponibilidade pela organização econômica, que não necessita de sua força de trabalho, e por isso mesmo encontrando quem dele disponha, para outras tarefas que não são as de produção." (p.42)

Os homens de nhô Augusto fazem parte dessa leva de homens sem identidade própria, com existência baseada na pessoa do senhor. Mesmo após a queda de nhô Augusto, eles mantêm-se obedientes a outro senhor, o Major Consilva.

O contrato estabelecido por Augusto e seus homens é quebrado devido ao fator financeiro; sem pagamento, não há lealdade, pelo menos não mais com o antigo patrão. Quando Quim traz a notícia da fuga da esposa com Ovídio, nhô Augusto manda chamar seus homens, mas estes já não trabalhavam mais para o mesmo senhor.

\footnotetext{
${ }^{87}$ Aliás, Dionóra, ao retornar com a filha para o Morro Azul, encontra-se com Ovídio Moura que possui na raiz do nome um sentido de recomeço ("ovo”).

${ }^{88}$ GALVÃO, Walnice Nogueira. “A plebe rural” In : As formas do falso, São Paulo, Ed. Perspectiva, 1986.
} 
“(...) os bate-paus não vinham... Não queriam ficar mais com nhô Augusto... O Major Consilva tinha ajustado, um e mais um, os quatro, para seus capangas, pagando bem. Não vinham, mesmo. O mais merecido, o cabeça, até mandara dizer, faltando ao respeito: _ Fala com nhô Augusto que sol de cima é dinheiro!... P'ra ele pagar o que está nos devendo... E é mandar por portador calado, que nós não podemos escutar prosa de outro, que seu Major disse que não quer." (p.332/33)

De qualquer forma, é notável a condição de dependência e submissão desses homens "livres" em relação aos senhores de terras - "os homens mais bravos e mais inúteis da nossa terra", conforme Euclides da Cunha afirmou ${ }^{89}$-; de Augusto ao Major a sua condição não muda, mantendo o sistema coronelista em pleno funcionamento.

Curioso notarmos que Augusto, como herdeiro de Coronel, pode ser considerado um, mas o personagem que toma posse do que é de nhô Augusto não é nomeado Coronel e, sim, Major. Esses títulos, emprestados do militarismo, e se assim os analisarmos, são diferentes quanto à importância de patente. Porém, a narrativa não nos dá indícios explicativos sobre o porquê dessa diferença; podemos destacar apenas que Coronel está numa posição acima do Major militarmente falando e, no entanto, é justamente a patente mais alta que perde o posto para outro de patente inferior.

Em todo caso, o que queremos frisar, neste primeiro momento na narrativa, é a afirmação e permanência do Coronelismo sertanejo em todo o seu vigor de funcionamento, sem brechas para o poder formal, pois, mesmo após a queda do Coronel Augusto, o lugar é ocupado por outro representante desse sistema, o Major Consilva. 


\subsection{Augusto Matraga: reconhecimento de um "mundo misturado" 90}

"No real da vida, as coisas acabam com menos formato, nem acabam. Melhor assim. Pelejar por exato, dá erro contra a gente. Não se queira." Grande Sertão: Veredas

O que chamamos aqui de segundo momento da novela tem início com o socorro dado pelo casal de pretos "que morava na boca do brejo" ao surrado e quase defundo nhô Augusto. Em meio à pobreza, simplicidade e humildade, o nosso personagem começará sua trajetória de renascimento, analisada por nós no segundo capítulo deste trabalho sob o ponto de vista mítico-estrutural.

Essa trajetória que agrega a Matraga novos valores pode representar também um início de novo senso de justiça e, por isso, um início de modernização democrática do sertão brasileiro, pensando aqui no momento histórico e político do país na época de publicação de Sagarana.

Em Grande Sertão, também há esse sentido do moderno adentrando o sertão quando Zé Bebelo é julgado aos moldes da justiça formal. Em "A hora e vez", certo é que não há um momento tão explícito e marcante que indique uma tentativa de aproximação do poder formal no interior brasileiro, mas podemos enxergar na mudança de ser de Matraga um reflexo desse moderno ou de um novo senso de justiça antes não existente nem para o personagem, nem para o povoado.

A trajetória de reconstrução do austero nhô Augusto aponta também para uma mudança de classe social: da "alta" para a miserável do brejo do casal de pretos. Sua posição, então, está enfraquecida, sem crédito para amizades, dinheiro ou política. Porém, como dissemos anteriormente, o sistema local não se enfraquece. Na sua fragilidade, nhô Augusto afasta-se para melhor pensar e se reencontrar, tendo de suportar todas as tentações do desejo de voltar a ser o velho guerreiro de respeito.

Joãozinho Bem-Bem aparece nesse ínterim como o representante da ordem local neste segundo momento. Sua caracterização é bem típica do valentão da tradição:

\footnotetext{
${ }^{89}$ Citado por Walnice Galvão. Op. cit. p.20.
} 
“... era o homem mais afamado dos dois sertões do rio: célebre do Jequitinhonha à Serra das Araras, da beira do Jequitibá à barra do Verde Grande, do Rio Gavião até nos Montes Claros, de Carinhanha até Paracatú; maior do que Antônio Dó ou Indalécio; o arranca-toco, o treme-terra, o come-brasa, o pega-à-unha, o fecha-treta, o tira-prosa, o parte-ferro, o rompe-racha, o rompe-e-arrasa: Seu Joãozinho BemBem." (p.348)

Matraga terá de ir contra aquilo que Ihe era perfeitamente normal quando ocupava a posição de Coronel - já começamos a notar essa nova postura na recusa de fazer parte do bando de Bem-Bem, apesar de, em pensamento, imaginar-se integrante dele:

“_ Ôpa! Ôi-ail... A gente botar você, mais você, de longe, com as clavinas... E você outro, aí, mais este compadre de cara séria, p'ra voltearem... E este companheirinho chegador, para chegar na frente, $e$ não dizer até-logo!... E depois chover sem chuva, com o pau escrevendo e lendo, e arma-de-fogo debulhando, e homem mudo gritando, e os do-lado-de-lá correndo e pedindo perdão!..." (р.353)

Então, a luta interna vivida por Matraga durante sua regeneração gira em torno de opostos: tradição e nova ordem. Esta será seguida com mais afinco, principalmente após a visita do padre que, nesse segundo momento, assim como o leiloeiro no primeiro, figura como o poder formal. Claro que, em primeiro lugar, ele figuraria o fator religioso presente na novela, mas serão as suas diretrizes, firmadas no trabalho humilde e na luta contra a violência - regras bastante formais -, que Matraga terá como novo lema.

\footnotetext{
${ }^{90}$ Expressão de Davi Arrigucci Jr., em seu ensaio “O mundo misturado: romance e experiência em Guimarães
} 
Aos poucos, lembrando aqui a estrutura mítico-religiosa da narrativa, o personagem passa a conceber o mundo e suas relações humanas de uma maneira diferente. Fábio de Souza Andrade ${ }^{91}$ diz que "o abrandamento da ótica costumeira em Matraga também passa por um questionamento ético que considera novas posições e resulta numa nova maneira de conceber o justo."

A ordem local rege conforme Bem-Bem afirma: "morte que eu mando é só morte legal", ou, pela ótica do costume, é morte "justa", dentro da lei local. Como também é considerada justa a morte do velho em lugar do assassino de Juruminho olhando de dentro não há nada mais "justo". Justiça aqui passa pela violência e bravura necessariamente.

Já pela ótica formal, esse comportamento é recusado e reprovado. Para evitar a violência, o também dividido Riobaldo propõe a prisão para Zé Bebelo em Grande Sertão; nada mais formal do que o aprisionamento em lugar da morte pura - novas maneiras de compreender as relações humanas que soam de modo estranho aos ouvidos da ordem local.

Para Bem-Bem também lhe é estranha a reação de Matraga contra a justiça local a ser feita (um dos filhos do velho deveria morrer, substituindo a morte de Juruminho, e suas filhas serviriam de diversão para os homens de Bem-Bem):

“- Não faz isso, meu amigo seu Joãozinho Bem-Bem, que o desgraçado do velho está pedindo em nome da Nosso Senhor e da Virgem Maria! E o que vocês estão querendo fazer em casa dele é coisa que nem Deus não manda e nem o diabo não faz!"

(...)

_ Você está caçoando com a gente, mano velho?" (p.367)

A nova concepção de justiça adquirida por Matraga sobressai-se à tradição. Mas, esta nunca é subjugada ou descartada. Esse novo justo banha-se nas águas

Rosa” In : Novos Estudos Cebrap, São Paulo, 40, 1994.

${ }^{91}$ ANDRADE, Fábio de Souza. Op. cit. p.156. 
da tradição e da nova ordem; "no sertão, o bem é violento e Deus traz sempre o porrete nas mãos"92. O fator que mais evidencia a mistura dos opostos é o respeito mantido por Matraga em relação ao valente Bem-Bem mesmo indo contra sua atitude - Matraga vai contra a ordem, respeitando-a e reconhecendo sua importância.

“- Pára com essa matinada, cambada de gente herege!... E depois enterrem bem direitinho o corpo, com muito respeito e em chão sagrado, que esse aí é o meu parente seu Joãozinho Bem-Bem!" (p.370)

Assim como há a acomodação da religião e da violência na terceira fase de sua trajetória mítica, também há o convívio entre poder formal (sentido modernoprogressista vigente na época) e informal (Coronelismo e suas articulações sóciopolíticas).

\footnotetext{
${ }^{92}$ ANDRADE, Fábio de Souza. Op. cit. p.156
} 


\section{CONCLUSÃO}

A atualização dos mitos ou narrativas míticas é, de fato, uma constante na literatura e, em escritores como Guimarães Rosa, essa releitura traz à tona tanto aspectos universais sobre o indivíduo e seus questionamentos internos, quanto aspectos locais/regionais que discutem a ação desse indivíduo no seu meio específico.

Quando Jolles, portanto, traz o conceito de que há a Forma Simples Mito (que permite identificar a história como sendo estruturalmente mítica) seguida de suas atualizações (que por sua vez, modificam, interferem e reelaboram o Mito), ele coloca que o mito nunca é estanque; ele é móvel e pode moldar-se conforme sua época - "mito vivo".

Esse moldar-se também vai ao encontro de outra teoria aqui seguida de Cornford (citada por Vernant), quando ele diz que o mito foi racionalizado, não no sentido de ter dado lugar à razão simples e pura, mas no sentido de trazer com ele questionamentos antes não colocados; de fato, como vimos, foi somente a partir do século VII que uma maior inquietação sobre o mundo e as relações humanas começou a surgir no mundo ocidental.

E a análise que propomos neste trabalho, apesar de priorizar a estrutura mítica da novela, também permite um diálogo com o viés histórico que pode conter "A hora e vez". Essa análise tentou estudar esse "mito racionalizado"; ou seja, tentou enxergar, em "A hora e vez", uma estrutura mítica na atualização do mito de regeneração (mito de Dionísio), discutindo também a situação histórica contida nela como reflexo de um momento bastante relevante do Brasil dos anos 30 e 40.

A transformação alcançada por Matraga em suas três fases, que analisamos neste trabalho, identifica a novela com a estrutura mítica, mais especificamente, com o mito dionisíaco de renascimento. A trajetória de queda e ascensão do nosso personagem aproxima quase que de imediato a narrativa rosiana do mito clássico grego. 
Em suas três fases, observamos que, para cada uma das duas primeiras, há um fator predominante, conforme a postura do personagem diante da vida, sendo a primeira fase caracterizada pela violência do anti-santo e a segunda pela religiosidade extrema de um personagem arrependido. A violência e a religião, portanto, vão permear a narrativa em seus altos e baixos até a acomodação pelo equilíbrio do mítico Matraga na figura do santo; mistura do velho e do novo homem. Nessa trajetória de queda e ascensão, como vimos, estão outras narrativas que também ilustram essa transformação, como a vida de São Francisco de Assis, cuja biografia assemelha-se com a de Matraga.

Porém, a análise seria insuficiente se apenas traçássemos esse paralelo entre as narrativas, deixando-se de lado todos os outros aspectos que vão além desse paralelismo.

Os elementos relacionados ao nome, à marca e à identificação com a natureza permitem-nos adentrar em âmbitos significativos para o conjunto da narrativa e até mesmo da obra Sagarana ${ }^{93}$. Na mudança do nome, teríamos nova aproximação do mito de Dionísio na raiz grega existente no nome Matraga, tragós, que significa "bode"; figura associada a Dionísio. Mas, também há o eco das maitacas "viajoras" que acompanham o personagem e, de certa forma, instiga-o a partir para a sua hora e vez. Na marca de ferro, que recebe após a surra, conforme vimos na análise de Walnice Galvão ${ }^{94}$, está a decifração do destino de Matraga; é uma marca de mudança do ser como assinatura de Deus. A totalidade desse ser é alcançada durante suas duas últimas fases, e isso podemos observar com a sua identificação com a natureza, pois o personagem passa a estar sensível ao mundo exterior desde os grunidos das galinhas até o pôr do sol alaranjado do sertão. Sua atitude é de contemplação do mundo exterior já que o mundo interior está apaziguado e reconstituído.

Enfim, esse ressurgimento (marcado na pele; possuidor de novo nome; e integrado ao mundo natural) acontece na figura do mítico Augusto Matraga - homem de novas experiências, mas consciente de sua realidade histórica. Por isso, o mítico

\footnotetext{
${ }^{93}$ Lembrando aqui a circularidade que pode haver em Sagarana nas semelhanças existentes entre a primeira e a última novelas da obra.

${ }^{94}$ GALVÃO, Walnice Nogueira. Op. cit.
} 
Matraga deixa também uma nova maneira de ver a vida e um novo tratamento humano para o Povoado. Ao mesmo tempo que defende um novo sentido de justiça, também respeita a ordem tradicional estabelecida.

Dialogando, assim, com o viés histórico, vemos que a trajetória de queda e ascensão de Matraga vivida em suas três fases aponta para dois momentos da narrativa que caracterizam historicamente sua postura. A primeira fase do anti-santo dialoga com o primeiro momento que chamamos de afirmação do Coronelismo local, pois o comportamento do personagem é baseado na tradição sertaneja, na qual o mais forte é quem manda. E a última fase dialoga com o segundo momento, quando Matraga reestrutura seus sentimentos na acomodação interior da violência e da religião, numa postura de equilíbrio entre a tradição e uma nova ordem do moderno (novo senso de justiça).

Portanto, a acomodação da violência e da religião dialoga com o momento histórico vivido pelo país, caracterizado pela incerteza e mistura de rumos.

Matraga deixa exemplo de comportamento para o Povoado não só em relação ao indivíduo e sua trajetória particular de vida, mas também exemplo de comportamento em relação ao tratamento humano - algo no Povoado muda no sentido único de cada ser que o compõe e no sentido coletivo com o ingresso de uma nova ordem ainda mesclada com a velha.

Nessas linhas - universal-mítica e regional-histórica - concebemos a atualização e a racionalização do mito, no caso, do mito dionisíaco de regeneração na figura do personagem Augusto Matraga, que teve a sua hora e vez, mas também permitiu a hora e vez do Povoado. 


\section{BIBLIOGRAFIA}

ANDRADE, Fábio de Souza. "Leilão divino, tribunal jagunço" In : Revista Literatura e Sociedade/ Dep. de Teoria Literária e Literatura Comparada/ Faculdade de Filosofia, Letras e Ciências Humanas/ Universidade de São Paulo - n. 6 (2002) -, São Paulo: USP/FFLCH/DTLLC, 2002.

ARISTÓTELES. Ética a Nicômaco. 3. ed. Brasília, Ed. UnB, 1997.

ARMSTRONG, Karen. Breve história do mito, São Paulo, Companhia das Letras, 2005.

ARRIGUCCI JR., Davi. "O mundo misturado" In : Cadernos de Pesquisa, São Paulo, Ed. Cortez, 1994.

Atualidade do Mito; tradução de Carlos Arthur R. do Nascimento (coletânea de artigos publicados na revista Esprit, $\mathrm{n}^{0}$ 402, abril de 1971). São Paulo, Duas Cidades, 1977.

AUERBACH, Erich. "A cicatriz de Ulisses" In : Mimesis. A representação do realismo na litaratura ocidental, São Paulo, Perspectiva, 1971.

BENJAMIN, Walter. "O narrador. Considerações sobre a obra de Nikolai Leskov" In : Obras escolhidas. Magia e Técnica. Arte e Política, São Paulo, Brasiliense, 1998. 
- "A crise do romance" In : Obras escolhidas. Magia e Técnica. Arte e Política, São Paulo, Brasiliense, 1985.

CANDIDO, Antonio. "O homem dos avessos" In : Tese e Antítese, São Paulo, Ed. Nacional, 1971.

. "Sagarana" In : COUTINHO, Eduardo. (org.) Guimarães Rosa. Fortuna Crítica, Rio de Janeiro, Civilização Brasileira, 1983.

CASCUDO, Luiz da Câmara. Dicionário do Folclore Brasileiro, São Paulo, Global Editora, 2001.

CHEVALIER, Jean. GHEERBRANT, Alain. Dicionário de Símbolos, Rio de Janeiro, José Olympio, 1999.

CUNHA, Antonio Geraldo. Dicionário etimológico Nova Fronteira da Língua Portuguesa, Rio de Janeiro, Nova Fronteira, 1996.

DE VARAZZE, Jacopo. (trad. do latim) Legenda Áurea (Legendae Sanatorum) Vida dos Santos, São Paulo, Companhia das Letras, 2003.

ELIADE, Mircea. Aspectos do mito, Lisboa, Perspectivas do Homem, Edições 70, 1963. . Mito e realidade, São Paulo, Ed. Perspectiva, 2000. 
FLAUBERT. "São Julião: o Hospitaleiro" In : Três contos, São Paulo, Melhoramentos, 1999.

FRANCO, Maria Sylvia. "A vontade santa" In : Trans/Form/Ação, São Paulo, n ${ }^{0} 2$, 1975

GALVÃO, Walnice Nogueira. As formas do falso, São Paulo, Ed. Cultrix, 1976. - "Matraga: sua marca" In : Mitológica Rosiana, São Paulo, Ed. Ática, 1978.

GIRARD, René. A violência e o sagrado, São Paulo, Ed. Universidade Estadual Paulista, 1990.

JOLLES, Andre. Formas Simples, São Paulo, Ed. Cultrix, 1976.

LEAL, Victor Nunes. "Indicações sobre a estrutura e o processo do "Coronelismo" In : Coronelismo, enxada e voto, Rio de Janeiro, Ed. Nova Fronteira, 1997.

LOPES, Paulo César Carneiro. Utopia Cristã no sertão mineiro: uma leitura de "A hora e vez de Augusto Matraga" de João Guimarães Rosa, Rio de Janeiro, Ed. Vozes, 1997. 
LINS, Álvaro. "Uma grande estréia" In : COUTINHO, Eduardo (org.). Guimarães Rosa. Fortuna Crítica, Rio de Janeiro, Civilização Brasileira, 1983.

NUNES, Benedito. "A viagem" In : O dorso do tigre, São Paulo, Ed. Perspectiva, 1969.

. "O mito em Grande Sertão: Veredas" In : Revista Scripta, Belo Horizonte, Ed. PUCMinas, v.2, n. 3, 2º semestre. 1998.

PROENÇA, Cavalcante. Trilhas do Grande Sertão, Rio de Janeiro, MEC, 1958.

RONCARI, Luiz. "Irmão Lélio, irmã Lina: incesto e milagre na "Ilha" do Pinhém" in : Estudos Avançados, São Paulo, n.42, v.15, 2001.

. O Brasil de Rosa, São Paulo, Ed. Unesp, 2004.

ROSA, João Guimarães . Sagarana, 20ª ed. Rio de Janeiro, José Olympio, 1977.

STARLING, Heloísa M. Murgel. "O sentido do moderno no Brasil de João Guimarães Rosa - veredas de política e ficção" In : Revista Scripta, n.3, v.2, Belo Horizonte, PUCMinas, $2^{\circ}$ semestre. 1998. 
VERNANT, Jean-Pierre. As origens do pensamento grego, São Paulo, Difel/Difusão Editorial SA, 1977.

- "Do mito à razão" In : Mito e pensamento entre os gregos: estudos de psicologia histórica, Rio de Janeiro, Ed. Paz e Terra, 1990.

. "Razones del mito" In : Mito y Sociedad en la Grecia antigua, Madrid, Siglo Veintiuno Editores, 1987. 